\title{
Is Q Fever an emerging or re-emerging zoonosis?
}

\author{
Nathalie ARRICAU-BOUVERY*, Annie RODOLAKIS \\ Pathologie Infectieuse et Immunologie, INRA, Centre de Tours-Nouzilly, 37380 Nouzilly, France
}

(Received 11 May 2004; accepted 13 December 2004)

\begin{abstract}
Q fever is a zoonotic disease considered as emerging or re-emerging in many countries. It is caused by Coxiella burnetii, a bacterium developing spore-like forms that are highly resistant to the environment. The most common animal reservoirs are livestock and the main source of infection is by inhalation of contaminated aerosols. Although the culture process for Coxiella is laborious, advances on the knowledge of the life cycle of the bacterium have been made. New tools have been developed to (i) improve the diagnosis of Q fever in humans and animals, and especially animal shedders, (ii) perform epidemiological studies, and (iii) prevent the disease through the use of vaccines. This review summarizes the state of the knowledge on the bacteriology and clinical manifestations of Q fever as well as its diagnosis, epidemiology, treatment and prevention in order to understand what factors are responsible for its emergence or re-emergence.
\end{abstract}

\section{Coxiella burnetii / epidemiology / bacteriology / diagnostic / control}

\section{Table of contents}

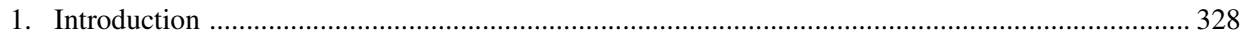

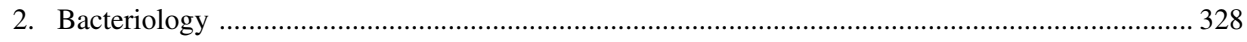

2.1. Large-cell variants, small-cell variants and small dense cells ......................................... 329

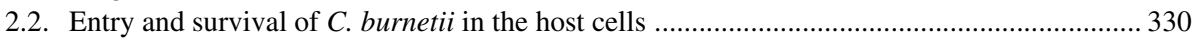

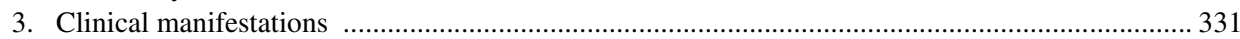

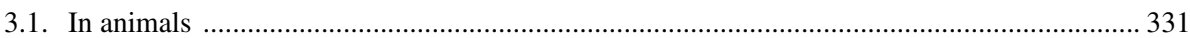

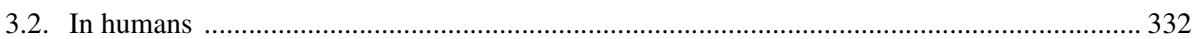

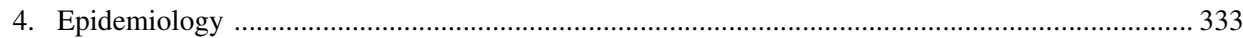

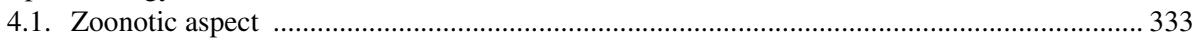

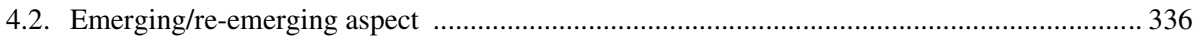

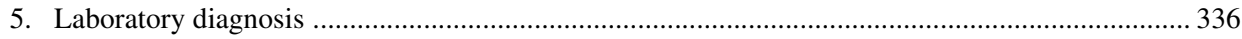

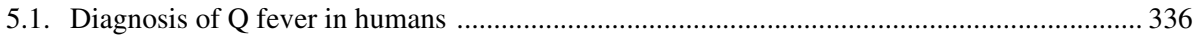

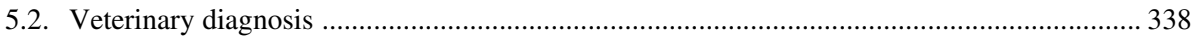

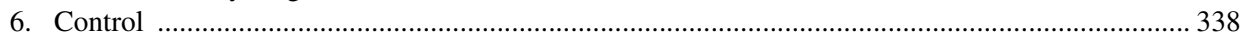

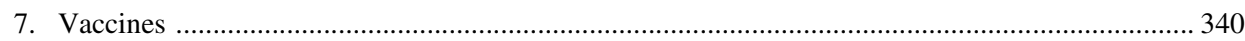

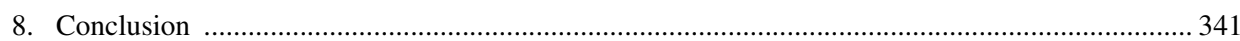

\footnotetext{
* Corresponding author: Nathalie.Bouvery@tours.inra.fr
} 


\section{INTRODUCTION}

Q fever (for query fever), is a zoonosis due to Coxiella burnetii a small intracellular bacterium. The disease has been known since the 1930s and has a worldwide distribution, with the exception of the Antarctica and possibly New Zealand [61], where its presence has not really been confirmed [52]. Indeed in 1990-1991, sera from 2181 aborting cattle and from 12556 sheepdogs were all seronegative for $\mathrm{Q}$ fever [61] but in 1997, since Q fever can be acquired following exposure to wild rabbits [99], it may have been introduced with the Rabbit hemorraghic disease virus illegally imported from Australia for rabbit control. Three out of 97 persons possibly exposed to the imported rabbit tissues were seropositive [52] but this result did not prove that they were contaminated by the rabbit material.

The interest for Q fever is increasing worldwide as indicated by the rising number of reviews published [44, 72, 82, 92, 97, $101,113,132,141,185]$ even in countries where its incidence is supposed to be very low. Indeed, the disease is considered as a re-emerging zoonosis in many countries. This could be due to the evolution of its epidemiology, or of the agent, which could become more virulent, to modifications of its clinical signs, to an improvement of the sensitivity of diagnostic tests, or because practitioners are better informed and look for it more often. This review summarizes the state of the knowledge of the bacteriology and clinical manifestations of Q fever as well as its diagnosis, epidemiology, treatment and prevention in order to understand what factors are responsible for its emergence or re-emergence.

\section{BACTERIOLOGY}

C. burnetii is a small pleomorphic Gramnegative bacterium. C. burnetii is an obligate intracellular bacterium that replicates to high numbers, although with an estimated slow doubling time (12-20 h), within the phagolysosome of the eukaryotic phagocyte $[53,187]$. The sequence of the complete genome of $C$. burnetii Nine Mile phase I RSA493 has been analyzed and suggests a circular topology for the chromosome. Although Coxiella was historically considered as a Rickettsia, gene-sequence analysis classifies the Coxiella genus in the order Legionellale, family Coxiellaceae with Rickettsiella and Aquicella [144]. The genome is predicted to encode 2134 coding sequences larger than 30 aa, of which 719 $(33.7 \%)$ are hypothetical. In contrast to other similar intracellular pathogens, Chlamydia [157], Rickettsia [115], Mycobacterium [33], C. burnetii possesses 29 insertion sequence (IS) elements. There are 21 copies of a unique IS110-related isotype, named IS1111, 5 IS30 and 3 ISAs1 family elements, and 3 degenerate transposase genes of unknown lineage [63]. Among the strains, four plasmid types designated QpH1, QpRS, QpDV and one plasmid without designation derived from a chinese $C$. burnetii isolate have been described $[60,70,88,112$, 163, 172]. Plasmidless $C$. burnetii strains carry large plasmid-homologous sequences integrated into the chromosome [181]. Although the plasmids seem to be of major importance for virulence because their common sequences are conserved among all isolates of Coxiella, their biological significance is still unclear. Initially, the plasmid profile was associated with the so-called acute or chronic $C$. burnetii isolates, originating respectively from acute or chronic $\mathrm{Q}$ fever patients. However, recent findings by PCR analysis of $C$. burnetii strains from patients exhibiting chronic Q fever have revealed that there is no correlation between the plasmid type and the acute or chronic human infection: the development of acute or chronic Q fever would rather depend on the patient's condition and immune status $[152,162]$.

The phase variation (phase I and phase II) phenomenon observed in C. burnetii is similar to the smooth to rough lipopolysaccharide (LPS) transition of Enterobacteriaceae [11]. LPS has been associated with bacterial 
virulence, especially in the resistance to complement-mediated serum killing, the entry of the bacteria in macrophages and their survival in host cells. Coxiella expressing a complete LPS structure are characterized as virulent phase I bacteria. Yet the LPS of C. burnetii has an endotoxic activity 100 to 1000 times lower than that of the LPS of Enteriobacteriaceae [4], but it induces the production of inflammatory cytokines in murine and human macrophages [35, 171]. Avirulent phase II bacteria are produced by spontaneous mutations or large genetic rearrangements that result in the synthesis of truncated forms of LPS, which lack the branched-chain sugars virenose and dihydrohydroxystreptose present in phase I LPS $[64,65,164]$. This phase variation is observed when Coxiella organisms are propagated in non-immunocompetent cell cultures or hen eggs and is irreversible [122]. The transition between the two phases is perhaps a strategy of Coxiella to by-pass the immune response of the host but phase II bacteria have not yet been isolated from the host [10].

\subsection{Large-cell variants, small-cell variants and small dense cells}

Pleomorphic bacteria have been identified in host cells as well as after purification and are classified into three groups: largecell variants (LCV), small-cell variants (SCV) and small dense cells (SDC). The first observations of the different forms of Coxiella were made through electron microscopic investigations [102]. The three forms can be distinguished by morphologic, antigenic and metabolic differences, and physical and chemical resistance [57]. The LCV, which share features common with Gram-negative bacteria, have diffuse chromatin and possess clearly distinguishable outer and cytoplasmic membranes with exposed LPS on the surface. They are larger, more pleomorphic and metabolically active and less electron dense than the SCV and SDC, which have condensed chromatin [102, 143]. The SDC resemble the SCV in morphology but are distinct from this form as a result of a higher physical stability [103]. The SDC have been visualized in LCV as endospores and may be liberated upon the lysis of LCV or binary transverse fission with unequal cell division [102]. Although, the SDC alone have never been isolated and purified, free-living amoebae can provide an intra-cellular niche for SDC formation and survival of $C$. burnetii in the environment [85]. Binary transverse fission was observed in both the SCV and LCV in cultured cells. The formation of the different forms is linked to the lifecycle of Coxiella, a strategy developed to survive in and out of the parasitophorous vacuole. These forms express different proteins specific for each form in the developmental life cycle [55-57, 143] and recognized by antibodies produced during a Coxiella infection. These differentially expressed antigens could allow the bacteria to escape the immune response by a switch of the exposed proteins on the surface of the bacteria and to survive in the acid vacuole. For example, unlike SDC, there are more $\mathrm{P} 1$ major outer membrane proteins in the LCV than in the SCV [103, 173]. This protein is able to form a pore within a planar lipid bilayer and functions as an anion-selective porin that permits the substrate to enter into LCV and SCV [136].

The SCV and SDC are considered as the probable persistent forms in the host and certainly the resistant forms of $C$. burnetii in the environment. Indeed high-level resistance to UV radiation, heat, desiccation, sonication, pressure (> $50000 \mathrm{psi}$; $1 \mathrm{psi}=6.89 \mathrm{kPa}$ ) and osmotic and oxidative stress has been described [3]. This resistance allows the bacteria to survive extracellularly as infectious particles for at least 150 days [177]. This remarkable resistance of $C$. burnetii is a specific trait of this strict intracellular bacterium and may explain its wide spread in the environment and its capacity to infect animals and humans for a long period after they have been excreted by a first host [153]. In spite of the identification of specific markers of the forms of Coxiella, the process of differentiation in $C$. burnetii has not been entirely elucidated. 


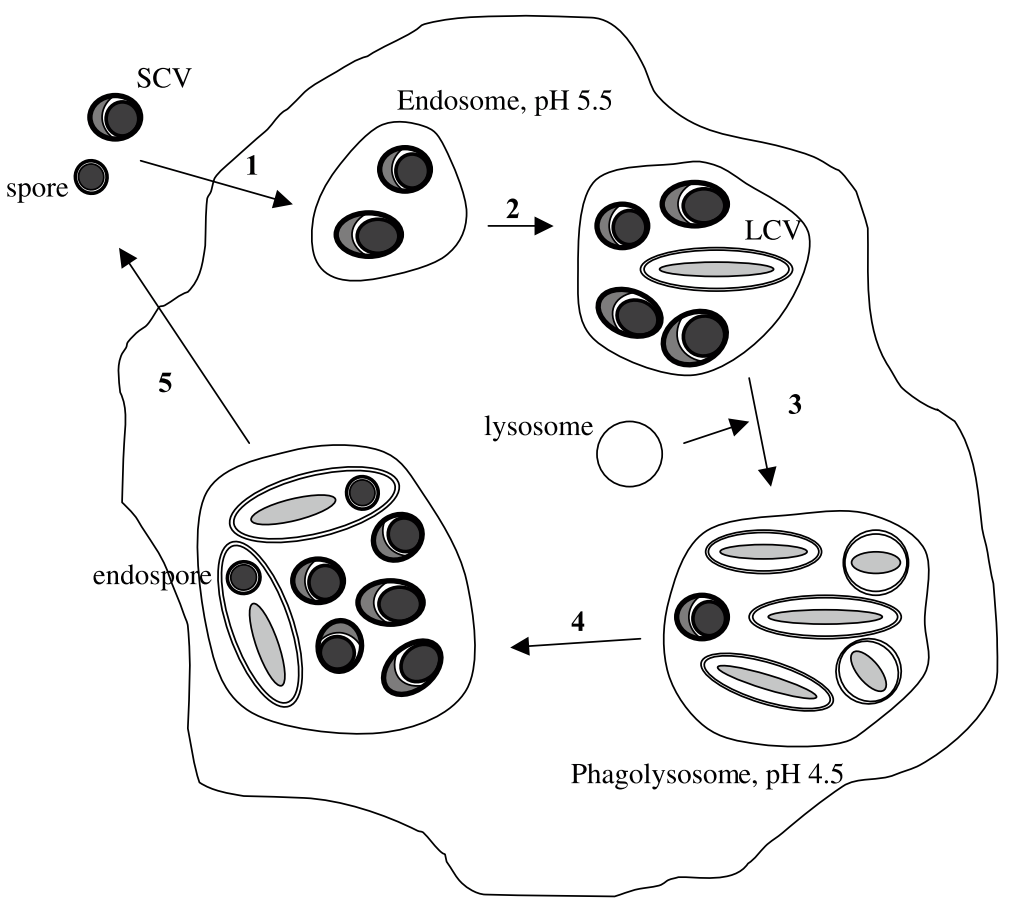

Figure 1. Model of the putative developmental cycle of C. burnetii in the eucaryotic cell. (1) Entry of the spore or SCV in the eucaryotic cell and acidification of the endosome (about $\mathrm{pH} 5.5$ ) of the phagosome. (2) Multiplication of small-cell variants (SCV) by transverse binary fission and differentiation to large-cell variants (LCV). (3) Fusion of the endosome with the lysosome, acidification of the phagolysosomal (about $\mathrm{pH} 4.5$ ). (4) Multiplication of LCV by transverse binary fission, differentiation of LCV to SCV and development of the polar endospore in LCV. (5) Release of the spore and SCV out of the cell.

The passage of SCV to LCV in the host cell is well documented [66], but the stress at the origin of the formation of SCV and SDC have not yet been studied. So these markers of LCV or SCV could allow studying and identifying the external and cellular signals that trigger the differentiation of the bacteria. Indeed, the physiological forms of the bacterium excreted in milk, feces or placentas are unknown. The form excreted by the host and the hypothetical possibility that LCV could convert to SCV in the environment are crucial information for implementing adequate strategies for the disinfection of feces or parturition products that could directly contaminate humans or the environment.

\subsection{Entry and survival of C. burnetii in the host cells}

C. burnetii infects a great number of cell types including, in vivo and in vitro, monocytes and macrophages and, in vitro, a variety of transformed cells (L929, HELA or VERO cells) [11]. This capacity to invade and subsequently to grow within such eukaryotic cells is an important factor of virulence of $C$. burnetii that allows its propagation in different niches of the host $[8,26$, 155]. C. burnetii survives and divides in a phagolysosome, which is an acidified environment (Fig. 1). The biphasic developmental cycle of $C$. burnetii in the host cell and the bacterial factors used for the intracellular survival are well documented in 
several reviews [57, 136, 159]. The small and large forms express different genes that permit the bacterium to survive in the specific harsh compartment of each form. For example, RpoS (sigma $S$ ) is a sigma subunit that confers promoter specific transcriptional initiation by RNA polymerase to genes that are expressed during the stationary phase in main bacteria. RpoS allows multistress resistance and causes morphologic and physiological alterations. SCV does not contain significant RpoS while LCV express abundant RpoS [142], suggesting that LCV and SCV life cycle variants may not be the functional equivalent forms of logarithmic- and stationary-phase bacteria as postulated earlier [57]. This sigma factor may regulate genes involved in surviving stresses in metabolically active LCV [107]. Moreover, the small forms are able to delay phagolysosomal fusion, perhaps to facilitate the transition from SCV to LCV that occurs at $\mathrm{pH} 5.5$ in the endosome [66]. The use of cellular markers (LAMP1, EEA.1, rab7) [67, 68] strongly suggests that the large replicative vacuoles containing Coxiella are derived from fusion with late endosomal-lysosomal organelles. Sequence homologies between the type IV secretion system proteins of Coxiella and Legionella strongly suggest that this secretion system should be involved in the maturation of the phagosome containing Coxiella [144]. Indeed, Coxiella encodes functional components of the type IV secretion system expressed in vivo during host cell infection [188]. Although the C. burnetii IcmQ protein and the Legionella $\mathrm{IcmR}$ protein do not interact, the $C$. burnetii secretion system is mechanistically related to the Legionella Dot/Icm apparatus [188, 193]. This secretion system could play an important role in creating the specialized vacuole that supports $C$. burnetii replication.

The uptake of virulent $C$. burnetii depends on $\alpha_{\mathrm{v}} \beta_{3}$ integrin and TLR 4 via phase I LPS [35]. TLR4 controls the early events of C. burnetii infection including macrophage phagocytosis, granuloma formation and cytokine production [62]. This receptor is not specific for humans and can also be found in insects [71, 174]. Thus, C. burnetii has developed a cell uptake strategy that allows it to invade a broad range of hosts and has developed a unique tactic to multiply in the harsh phagolysosome environment of the cells. Indeed, C. burnetii has been isolated from a lot of different hosts such as amoebae, ticks, birds and mammals, contributing (i) to favor its spread in the environment where it can survive for very long periods of time and (ii) to infect people. However no data are available on the evolution of virulence factors of $C$. burnetii strains that could explain the recent increase of cases of Q fever in humans.

\section{CLINICAL MANIFESTATIONS}

\subsection{In animals}

C. burnetii is able to infect many animal species including mammals, birds and arthropods. In animals, $C$. burnetii infections are generally asymptomatic but in mammals they can lead to abortions and stillbirths [86]. In these animals, C. burnetii can induce pneumonia as well as abortion, stillbirth and delivery of weak lambs, calves or kids, which are the most frequent clinical signs of the disease. In the majority of cases, abortion occurs at the end of gestation without specific clinical signs until abortion is imminent, as observed with brucellosis or chlamydiosis. Aborted fetuses appear normal but infected placentas exhibit intercotyledonary fibrous thickening and discolored exudates, which are not specific to $\mathrm{Q}$ fever. A severe inflammatory response is observed in the myometrium and the stroma adjacent to the placentomal area during gestation in goats ${ }^{1}$. Trophoblast cells appear altered and

\footnotetext{
${ }^{1}$ Navarro J.A., Souriau A., Buendia A.J., Martinez C.M., Sanchez J., Arricau-Bouvery N., Rodolakis A., Salinas J., Experimental Coxiella burnetii infection in pregnant goats: an immunohistochemical study, Proc. 20th Meeting of the European Society of Veterinary Pathology, 2002, p. 188.
} 
Table I. The longest observed duration of excretion of Coxiella burnetii in vaginal mucus, milk, and feces of ruminants during the follow-up of naturally or experimentally infected herds.

\begin{tabular}{lccc}
\hline \multirow{2}{*}{ Ruminant species } & \multicolumn{3}{c}{ Duration of $C$. burnetii shedding } \\
\cline { 2 - 4 } & Vaginal mucus & Feces & Milk \\
\hline Cow & ND & 14 days [86] & 13 months [20] \\
Goat & 14 days [8] & 20 days [8] & 52 days [8] \\
Ewe & 71 days [16] & 8 days after lambing & 8 days [10, 16] \\
& & {$[10,16]$} & \\
\hline
\end{tabular}

ND: not determined.

foamy, with well defined C. burnetii inclusions, also found in multinuclear cells. The abortion rate can range from 3 to $80 \%$ of pregnant females $[16,116,189]$. High abortion rates are rarely observed, except in some caprine herds [116]. Often, the number of females that abort in the flock may not be enough to alert the farmer and human clinical cases often reveal the infection of the flock [18]. In cattle, metritis is frequently the unique manifestation of the disease [168]. Aborting females recover rapidly and generally do not abort during the following gestations, while metritis can persist for several months. Infected mammals (ruminants, cats, dogs, rabbits, small wild rodents, ...) shed $C$. burnetii in birth products but also in milk, urine and feces (Tab. I). Aborting females but also females with normal parturition as well as cows suffering from metritis can shed C. burnetii in milk for several months, even during several milking periods [10, 167]. Milk shedding is more frequent and lasts longer in cows and goats than in ewes [86]. Ewes shed more and longer in vaginal discharges than goats, and can shed bacteria at subsequent pregnancies [17]. Goats shed C. burnetii in feces before and after kidding and the mean duration of excretion is 20 days when they are experimentally infected at 90 days of gestation [8]. Natural infected ewes shed C. burnetii in feces during 8 days after lambing [16] and before lambing this excretion has not yet been studied.

\subsection{In humans}

C. burnetii in humans causes highly variable clinical manifestations ranging from acute to fatal chronic infections. However, about $60 \%$ of the infections are asymptomatic seroconversions.

Acute $\mathrm{Q}$ fever is mainly a flu-like disease, or atypical pneumonia or hepatitis [101]. The self-limited febrile illness with flu-like symptoms is characterized by a sudden onset, high-grade fever, reaching $40{ }^{\circ} \mathrm{C}$, severe headache, weight loss, myalgy, and cough [101]. In some cases, skin rash, nausea, raise in transaminase levels, arthralgia, chills, sweating and photophobia can be observed. If untreated, fever lasts $1-3$ weeks but in some patients fever can persist longer [95].

- Atypical pneumonia is generally associated with fever, headache, and myalgia. Cough is nonproductive and may be absent despite the presence of pneumonia [96]. Sometimes pleuritic chest pain, which can be very severe, is reported [95]. While in most instances patients present minimal changes at auscultation, some of them progress to severe respiratory distress.

- Hepatitis could be asymptomatic and is characterized by a raise in the transaminase levels alone or associated with a prolonged fever of unknown origin or by an infectious hepatitis rarely with jaundice [43] but with hepatomegaly.

- Various clinical signs of acute Q fever have also been less frequently described 
[72, 92, 101]: they include meningoencephalitis, severe headache, pericarditis, pancreatitis and abortion.

In about $5 \%$ of the cases, the disease may become chronic leading to an often fatal endocarditis, chronic fatigue syndrome and repeated abortions.

- Endocarditis is the most frequent and the most severe manifestation of chronic $\mathrm{Q}$ fever, and represents about 1.5-2\% of human cases of endocarditis. It generally occurs several months or years after the acute infection in patients with prior valvulopathy $[123,169]$ or who acquired immunosuppression, [124]; however other authors from Spain found that C. burnetii is not more frequent in HIV-infected patients than in other patients [110].

- Chronic fatigue syndrome characterized by an inappropriate fatigue, myalgia, arthralgia, night sweats and changes in moods and sleep patterns has been particularly described in Australia [9, 93]. It may persist after an acute episode of Q fever and last several months or years. It may be induced by cytokine dysregulation, mainly by high concentrations of interleukine 6 [118].

- In pregnant women, C. burnetii can cause placentitis leading to abortion, neonatal death, premature birth and low birth weight, but it may also induce asymptomatic infection [37, 59, 87, 97, 126]. The risk of chronic $Q$ fever leading to repeat miscarriage is very high when the infection occurs during pregnancy [126].

\section{EPIDEMIOLOGY}

\subsection{Zoonotic aspect}

Q fever is essentially an airborne disease. Infections occur after inhalation of aerosols generated from infected placentas, body fluids or contaminated dust resulting from contaminated manure and desiccation of infected placenta and body fluids. Transmission of $C$. burnetii is mostly associated with abortion of domestic ruminants and particularly with ovine abortions. Several authors have described a seasonal variation in the incidence of the human disease in the spring and early summer which has been attributed to spring lambing and shearing leading to environmental contamination [58, 166]. Indeed, direct contact with aborted females is not required. People may be infected by handling contaminated wool [2], manure [18] or clothes contaminated with feces [10] or transhumance of infected flocks through a valley [38]. Furthermore, between June and November 2002, in the Chamonix valley in France, 88 human cases of Q fever were identified, 71 with clinical signs and 10 who needed hospitalization. The origin of this outbreak has been supposed to be due to airborne transmission from some infected flocks present in the valley since June ${ }^{2}$.

In the USA, $C$. burnetii is enzootic in ruminants and wild animals as in other parts of the world [105], but human infections due to $C$. burnetii are rare $[48,105]$. The most recent cases of $\mathrm{Q}$ fever have been described in Australia [50, 148, 186], Canada [87, 94], France [125, 165], Germany [58], Japan [160], Spain [34, 135], Switzerland and the United Kingdom [117]. Little information is available to explain such an increase of cases of $Q$ fever except perhaps in Bulgaria where the rise of the number of goats that daily go through villages and small towns for grazing is associated with an increase in human $\mathrm{Q}$ fever [141]. The increased interest for camping on farms or for visits of young pupils coming with some mothers to "educational ruminant farm visits", where they are in contact with newborn kids and lambs, multiplies the exposure of susceptible persons to $C$. burnetii and can lead to the emergence of Q fever ${ }^{3}$. The prevalence of Q fever in humans as well as in animals is not known

\footnotetext{
2 http://www.sante.gouv.fr/htm/actu/actu_ss/

3 Brugère-Picoux J., Granström M., Zoonosis linked to "educational ruminant farms visits", Proceeding of 3rd Congress of European Society for Emerging Infection, ENV Alfort, 2004, p. 55.
} 
Table II. Seroprevalence of Q-fever in humans obtained in the main recent worldwide outbreaks.

\begin{tabular}{|c|c|c|c|c|c|c|}
\hline Country & Year & No. of exposed persons & $\begin{array}{l}\text { No. of } \\
\text { towns }\end{array}$ & $\begin{array}{l}\text { Test } \\
\text { used }\end{array}$ & $\begin{array}{l}\text { Seroprevalence in } \\
\text { human persons } \\
(\%)\end{array}$ & Ref. \\
\hline Poland & 2003 & $\begin{array}{l}90 \text { (farming) } \\
30 \text { (urban) }\end{array}$ & $\begin{array}{c}11 \text { (village) } \\
1 \text { (town) }\end{array}$ & $\mathrm{IF}^{\mathrm{a}}$ & $\begin{array}{c}18 \\
0\end{array}$ & [32] \\
\hline $\begin{array}{l}\text { Canary } \\
\text { Island }\end{array}$ & 2003 & 662 & ND & IF & 36 & {$[22]$} \\
\hline Japan & 2001 & $\begin{array}{l}267 \text { (veterinarians) } \\
352 \text { (medical workers) } \\
2003 \text { (blood donors) }\end{array}$ & ND & IF & $\begin{array}{c}13.5 \\
5 \\
4\end{array}$ & [1] \\
\hline Japan & 2000 & 200 (pregnant) & 1 & IF & 4 & [114] \\
\hline Taiwan & 2000 & 616 & ND & IF & 4 & [77] \\
\hline Chad & 1999-2000 & 368 & 32 & ELISA $^{b}$ & 1 & [139] \\
\hline Turkey & 1998 & 102 & ND & IF & 8 & {$[30]$} \\
\hline Canada & 1997-1998 & 7658 (pregnant) & ND & IF & 4 & [87] \\
\hline Spain & 1996-1997 & 1654 & ND & IF & 5 & [90] \\
\hline France & 1996 & 12716 & 3 & IF & 0.15 & [129] \\
\hline France & $\begin{array}{l}1995 \\
1996\end{array}$ & $\begin{array}{l}790 \text { (blood donors) } \\
620 \text { (blood donors) } \\
785 \text { (general population) }\end{array}$ & 1 & IF & $\begin{array}{c}0.4 \\
3 \\
5\end{array}$ & [28] \\
\hline
\end{tabular}

a IF = immunofluorescence.

${ }^{\mathrm{b}}$ ELISA = enzyme-linked immunosorbent assay. ND: not determined.

accurately, and is probably underestimated since the multiple forms of the disease hinder its clinical diagnosis. Seroprevalence studies performed on blood donors suggest that exposure to $C$. burnetii is common in the countries where testing is performed (Tab. II). Few recent studies has been performed on animals (Tab. III), but they indicate that the disease is endemic worldwide.

The environmental survival of $C$. burnetii allows it to be transported by wind far away from its original source $[28,58,91]$. This could account for the appearance of $\mathrm{Q}$ fever cases in urban areas, where an important percentage of patients fails to report direct contact with animals [135]. Wild and domestic birds, which are able to transmit $\mathrm{Q}$ fever via their feces or their ectoparasites, can also be responsible for human cases in urban areas or apparently without animal contact. The airborne transmission of $C$. burnetii associated with its resistance and the ability to easily produce large quantities of $C$. burnetii in the placentas of aborted ewes or goats have led to classify $C$. burnetii as a category $\mathrm{B}$ biological terrorist agent $[72,92]$ although the great number of asymptomatic infections limits the consequences of its use as a biological weapon. It was perhaps used for this purpose during World War II [92]. This classification has been responsible for the publication of several reviews on Q fever [44, 72, 82, 92, 97, $101,113,132,141,185]$. It has focused the attention of medical and public health personnel on Q fever, which could be responsible for the apparent increase of recognized cases of Q fever and for its apparent re-emergence.

The ingestion of contaminated raw milk or raw milk products is a less efficient route of contamination [13]. Drinking contaminated milk has induced seroconversion in human volunteers without clinical signs [13, 83], 
Table III. Seroprevalence of animal Q-fever obtained in the main recent worldwide surveys.

\begin{tabular}{|c|c|c|c|c|c|}
\hline Country & Year & $\begin{array}{c}\text { No. of animals } \\
\text { tested }\end{array}$ & $\begin{array}{l}\text { No. of } \\
\text { herds }\end{array}$ & Test used & $\begin{array}{c}\text { Seroprevalence } \\
\text { of animals } \\
\text { (\% of herds) }\end{array}$ \\
\hline
\end{tabular}

\begin{tabular}{|c|c|c|c|c|c|c|}
\hline \multicolumn{7}{|l|}{ Cattle } \\
\hline Chad & 1999-2000 & 195 & 19 & ELISA $^{\mathrm{a}}$ & $4(37)$ & [139] \\
\hline Turkey & 1998 & 416 & 48 & $\mathrm{IF}^{\mathrm{b}}$ & 6 & {$[30]$} \\
\hline Germany & 1998 & 21191 & ND & ELISA & 8 & [58] \\
\hline Italy & 1998 & $\begin{array}{l}544 \\
486 \\
155\end{array}$ & $\begin{array}{c}21^{\mathrm{c}} \\
26^{\mathrm{d}} \\
6^{\mathrm{e}}\end{array}$ & IF & $\begin{array}{c}13 \\
20 \\
2\end{array}$ & [27] \\
\hline \multicolumn{7}{|l|}{ Sheep } \\
\hline Italy & 1999-2002 & 7194 & 675 & ELISA & $9(38)$ & [100] \\
\hline Chad & 1999-2000 & 142 & 28 & ELISA & $11(43)$ & [139] \\
\hline Germany & $\begin{array}{l}1998 \\
1999\end{array}$ & $\begin{array}{c}1346 \\
100\end{array}$ & $\begin{array}{c}\mathrm{ND} \\
1\end{array}$ & ELISA & $\begin{array}{l}1.3 \\
57\end{array}$ & [58] \\
\hline Turkey & 1998 & 411 & 47 & IF & 10.5 & [30] \\
\hline \multicolumn{7}{|l|}{ Goat } \\
\hline Italy & 1999-2002 & 2155 & 104 & ELISA & $13(47)$ & [100] \\
\hline Chad & 1999-2000 & 134 & 28 & ELISA & $13(46)$ & [139] \\
\hline Germany & 1998 & 278 & ND & ELISA & 2.5 & [58] \\
\hline \multicolumn{7}{|l|}{ Other } \\
\hline Japan & 2003 & $\begin{array}{l}310 \text { pet cats } \\
36 \text { stray cats }\end{array}$ & ND & IF & $\begin{array}{l}14 \\
42\end{array}$ & [79] \\
\hline Korea & 2003 & 116 pet cats & ND & IF & 9 & [79] \\
\hline Chad & 1999-2000 & 142 camels & 14 & ELISA & $80(100)$ & [139] \\
\hline Indonesia & 1999 & 327 rats & 2 & IF & 0 & [69] \\
\hline
\end{tabular}

a ELISA = enzyme-linked immunosorbent assay.

b IF = Immunofluorescence.

c Cattle housed throughout the year.

$\mathrm{d}$ Cattle housed in the winter and turned out to graze in the spring.

e Cattle kept outside throughout the year.

ND: not determined.

but none of them presented aggravating risk factors. However some studies have reported clinical disease linked to the ingestion of cheese [41, 54], but these results are sometimes contested since it is difficult to guarantee even for prisoners that the patients did not inhale contaminated dust or aerosols. Furthermore, nothing is known about the ingestion of massive doses of $C$. burnetii or of a moderate dose by persons at risk, such as pregnant women, immunocompromised patients, or patients with valvulopathy. In domestic animals, the oral route of contamination of cattle sheep and goats by ingestion of infected placentas is also considered as minor although it was not studied. However it is classically admitted that cats and dogs can be infected by the ingestion of placentas which are heavily infected (about $10^{9}$ bacteria per gram) [10]. 
Ticks are also considered to be a major reservoir and vector of $C$. burnetii in several countries. The reference strain Nine Mile was isolated from a tick in the USA [36]. $C$. burnetii is able to infect more than 40 species of ticks but their role in the transmission of the disease seems to be variable according to the country $[82,89,104,150]$. In France, this principally concerns wild and seldom concerns farm animals [83]. Ticks transmit the agent via a bite or feces to birds, rodents and ruminants [86]. Infection of the ovaries of certain ticks has been reported and may lead to germinative transmission to their progeny allowing $C$. burnetii to persist in the tick population [86].

\subsection{Emerging/re-emerging aspect}

The number of publications on outbreak (Tab. IV) and on retrospective studies of isolated cases or on uncommon clinical manifestations (meningitis and neurological manifestations $[14,29,84,111,119$, $120,137,146]$, myocarditis [45, 106, 108], lymphadenitis $[6,161]$, bone marrow granulomatosis [24, 128] and pancreatitis [154]) has been growing since 1999. However this increase may only reflect a higher awareness of the disease rather than really its emergence. In humans, clinical signs vary according to country but also with the sex and age of the patient. Infection in nonpregnant women and children is more frequently asymptomatic. Atypical pneumonia is the major manifestation of Q fever in older patients [101] and in the majority of patients from reported outbreaks in different countries (Nova Scotia Canada [98], Greek Island of Crete [170], Italy [138], Japan [160], Switzerland [38] and the United Kingdom). In other countries such as Australia, California and France [101], hepatitis and isolated or prolonged fever are the most common manifestations. In Spain and particularly in Catalonia [135] and in the Basque country [109, 145], atypical pneumonia is mainly reported while in Andalusia $[34,90,131]$ hepatitis and isolated or prolonged fever have been reported. The explanation of such differences is still unknown and could be due to differences of virulence between strains. Indeed, $C$. burnetii strains isolated from bovine milk are less virulent in a guinea pig model than those isolated from ticks [78]. In addition it would be interesting to know if virulence factors of the bacteria could be responsible for the severity of the disease in some caprine flocks where more than $30 \%$ of the pregnant females aborted while others were asymptomatic but shed the bacteria for several months. Currently, epidemiological antigenic and genomic markers are still missing or are currently being developed. However, recent studies have used different techniques to study the epidemiology of $\mathrm{Q}$ fever $[80,100]$.

\section{LABORATORY DIAGNOSIS}

Since there is no specific symptom of $Q$ fever, suitable laboratory tests are required for accurate diagnosis. The diagnosis of $\mathrm{Q}$ fever remains difficult and epidemiological studies are often based on serological investigations. C. burnetti does not grow on standard laboratory bacteriological media and its isolation is long, difficult and hazardous to perform. Since it requires biosafety level 3 conditions, it is rarely performed for routine diagnosis in veterinary medicine and restricted to specialized laboratories using the shell-vial cell culture technique [44]. Recently, the polymerase chain reaction (PCR) has radically changed the diagnosis of Q fever for humans and in veterinary medicine: PCR kits are becoming available and provide a specific, sensitive and rapid tool for the detection of $C$. burnetii in various clinical samples.

\subsection{Diagnosis of $\mathbf{Q}$ fever in humans}

The diagnosis of $\mathrm{Q}$ fever is mainly based on serological analysis and the immunofluorescence assay remains the most common method used to detect antibodies against C. burnetii [44, 82] because it is simple, accurate and allows the distinction between 
Table IV. Main outbreaks of Q fever described since 1999.

\begin{tabular}{|c|c|c|c|c|c|c|c|}
\hline \multicolumn{2}{|c|}{ Year } & \multirow{2}{*}{ Country } & \multirow{2}{*}{ Source } & \multirow{2}{*}{$\begin{array}{l}\text { No. of } \\
\text { cases }\end{array}$} & \multirow{2}{*}{$\begin{array}{c}\text { Main } \\
\text { Clinical signs }\end{array}$} & \multirow{2}{*}{ Diag } & \multirow{2}{*}{ Ref. } \\
\hline Publi $^{\mathrm{a}}$ & Outbreak & & & & & & \\
\hline 2004 & 2003 & Italy & Ovine & 133 & Fever, cough & $\mathrm{IF}^{\mathrm{b}}$ & {$[138]$} \\
\hline 2003 & 2002 & France & ovine & 88 & Fever, headache, ITL $^{\mathrm{c}}$ & IF & d \\
\hline 2003 & 2000 & France & Goat manure & 10 & $\begin{array}{c}\text { Fever, myalgy, sweat } \\
\text { headache, }\end{array}$ & IF & $\mathrm{e}$ \\
\hline 2003 & 2000 & France & Ovine manure & 5 & Fever, headache, ITL & IF & {$[18]$} \\
\hline 2003 & 2000 & Australia & unknown & 16 & Non described & $\mathrm{CFT}^{\mathrm{f}}$ & [31] \\
\hline 2003 & 1997 & Bosnia & ovine & 26 & $\begin{array}{l}\text { Malaise, fatigue, } \\
\text { headache, fever }\end{array}$ & serology & [149] \\
\hline 2003 & unknown & Japan & Dogs \& cats & 2 & asymptomatic & IF \& PCR & {$[80]$} \\
\hline 2002 & 1996 & France & ovine & 29 & Fever, myalgy ITL & IFI & [28] \\
\hline 2002 & unknown & Japan & $\begin{array}{l}\text { Travel in } \\
\text { Australia }\end{array}$ & 3 & Fever, fatigue, ITL & IF \& PCR & [73] \\
\hline 2001 & 1999 & Israel & $\begin{array}{c}? \\
\text { kitchen } \\
\text { workers }\end{array}$ & 16 & $\begin{array}{c}\text { Fever, headache, } \\
\text { Hepatitis pneumonia }\end{array}$ & ELISA & {$[156]$} \\
\hline 2001 & 1998 & Australia & $\begin{array}{c}\text { Ovine } \\
\text { Abattoir } \\
\text { employees }\end{array}$ & 33 & $?$ & $\begin{array}{l}\text { Serology \& } \\
\text { PCR }\end{array}$ & {$[51]$} \\
\hline 2001 & 1996-2000 & French Guiana & Wild reservoir & 132 & pneumopathy & IF & [49] \\
\hline 2001 & 1999 & Newfoundland & goat & 60 & $\begin{array}{l}\text { ITL, headache malaise, } \\
\text { fever }\end{array}$ & IF & {$[54]$} \\
\hline 2000 & unknown & $\begin{array}{c}\text { The } \\
\text { Netherlands }\end{array}$ & $\begin{array}{l}\text { vacation in } \\
\text { France }\end{array}$ & 4 & pneumonia, hepatitis & serology & {$[158]$} \\
\hline 2000 & 1999 & Germany & $\begin{array}{l}\text { Ovine, dung, } \\
\text { manure }\end{array}$ & $?$ & $?$ & $?$ & [127] \\
\hline 2000 & $?$ & Kenya & goat & 4 & $\begin{array}{c}\text { Fever, headache, } \\
\text { pneumonia }\end{array}$ & IF & {$[121]$} \\
\hline 1999 & 1990-1995 & France & ovine & 289 & Fever, headache, ITL & IF & [166] \\
\hline 1999 & 1987-1988 & Italy & ovine & 235 & Flu like syndrome & $?$ & [23] \\
\hline $\begin{array}{l}\text { a Year } \\
\text { b IF = } \\
{ }^{c} \text { ITL } \\
{ }^{d} \text { wwy } \\
\text { e wwy } \\
{ }^{\text {f }} \text { CFT }\end{array}$ & $\begin{array}{l}\text { dblicatio } \\
\text { unofluor } \\
\text { rease of } \\
\text { e.gouv.f } \\
\text { sante.fr } \\
\text { mplemer }\end{array}$ & $\begin{array}{l}\text { nce. } \\
\text { saminase leve } \\
\text { n/actu/actu_s } \\
\text { lications/200 } \\
\text { xation test. }\end{array}$ & $\begin{array}{l}\text { ls. } \\
\text { //fievre_q/ }\end{array}$ & & & & \\
\hline
\end{tabular}

acute and chronic $\mathrm{Q}$ fever using phase I and phase II antigens. Acute $\mathrm{Q}$ fever is characterized by a level of antibodies against the phase II antigen higher than those against the phase I antigen while a high level of antibodies to phase I antigen is associated with chronic Q fever [44]. For direct diag- nosis, PCR is a rapid technique: several primers specific to super oxide dismutase [151], 16S tRNA [180] or the htpAB repetitive element [180] have been developed and, especially for htpA, have been successfully used in a LightCycler Nested PCR being thus very efficient for early diagnosis [42]. 


\subsection{Veterinary diagnosis}

Routine diagnosis of $\mathrm{Q}$ fever in aborted ruminants is generally performed by the detection of bacteria in smears or impressions of placentas stained by the Stamp, Gimenez or Machiavello methods and combined with the serological analysis of at least ten sera samples by the complement fixation (CF) test, or better by ELISA [81]. The presence of very small red-colored coccobacilli, which must be differentiated from Chlamydophila and Brucella may be presumptive of Q fever. The CF test is still the OIE reference test: it is however weakly sensitive and the antigen used in this test frequently fails to detect antibodies in some animals. Moreover few sheep or goats may be seropositive without any clinical signs. The cut off value used for the diagnosis of chlamydiosis is often used for $\mathrm{Q}$ fever, inducing lots of mistakes because the cut off value in chlamydiosis takes into account the low antibody titers due to cross reaction with Chlamydophila pecorum. The species-specific indirect immunofluorescence assay (IFA) is not often used for diagnosis of $\mathrm{Q}$ fever in animals because it is inconvenient for large-scale screening, cannot be automated and could be subjective. No commercial kit using IFA for veterinary investigation is available. The ELISA and IFA tests are more sensitive than the $\mathrm{CF}$ tests for detection of antibody response in animal or humans with acute $\mathrm{Q}$ fever, but not for the detection of antibody response of humans with chronic Q fever and of aborting cows $[40,81]$. They allow detection of antibodies in human and animal acute-phase sera before $\mathrm{CF}$ tests that are not specific for Q-fever IgM, as are IgM IFA and IgMELISA tests. Recent $\mathrm{Q}$ fever infection is difficult to diagnose by $\mathrm{CF}$ tests because antibodies detected by the CF test can persist after acute disease. ELISA and microimmunofluorescence (MIF) tests give similar results with cow sera, but the ELISA test is more sensitive than the MIF test with goat and sheep sera [81]. ELISA tests allow testing a greater number of animals and flocks. But all these tests do not allow the individual identification of animals that shed $C$. burnetii in the feces or milk, since there is no true relationship between the serological response and excretion: even though most animals that excrete $C$. burnetii in the vaginal mucus, feces or milk are seropositive, on the one hand a few ones can be seropositive without shedding $C$. burnetii and on the other hand some animals can excrete and remain seronegative [16]. This last situation has an important consequence for animal and public health, and PCR is one of the most sensitive and rapid means to identify shedders. Moreover, only PCR allows the detection of metritis due to C. burnetii and the association of PCR and ELISA, which is to date the best way to diagnose $\mathrm{Q}$ fever in ruminants, could be partially responsible for the apparent emergence of Q fever as a result of an increased number of positive diagnostics $[15,16]$.

\section{CONTROL}

Since human-to-human transmission is extremely rare and Q fever is mainly an airborne disease, measures of prevention are aimed at avoiding the exposure of humans and particularly persons at risk, to animal and environmental contamination. To prevent and reduce the animal and environmental contamination, several actions can be proposed. Specific caution must be taken when introducing a new animal into a $Q$ feverfree flock, in order to avoid the spread of infection. An antibody investigation for $\mathrm{Q}$ fever should be performed in the flock of the seller and animals from seropositive flocks can only be introduced in seropositive or vaccinated flocks.

Since parturition is critical for the transmission of the disease, in infected flocks, birth must take place in a specific location, which must be disinfected as well as every utensil used for delivery. Placentas and fetuses must be picked up and destroyed as soon as possible in order to prevent their ingestion by domestic or wild carnivores, 
Table V. Impact of antibiotic treatment on the shedding of $C$ burnetii.

\begin{tabular}{|c|c|c|c|c|c|}
\hline $\begin{array}{l}\text { Number of } \\
\text { animals }\end{array}$ & Dosage & Technique & Sample & $\begin{array}{l}\text { Number of } \\
\text { positive }(\%)\end{array}$ & Ref. \\
\hline \multicolumn{6}{|l|}{ Cattle } \\
\hline 2 & $\begin{array}{c}8 \mathrm{~g} / \mathrm{kg} \text { chlortetracycline each } \\
\text { day } 30 \text { days }\end{array}$ & Mouse inoculation & milk & $0 / 2^{b}$ & {$[178]$} \\
\hline 33 & $\mathrm{LAT}^{\circledR a} 50 \mathrm{~mL} / \mathrm{cow}$ & Stamp & Placenta & $8 / 33(24)$ & [19] \\
\hline 27 & Control & Stamp & Placenta & $7 / 27(26)$ & [19] \\
\hline \multicolumn{6}{|l|}{ Sheep } \\
\hline $25^{\mathrm{c}}$ & $\begin{array}{c}\text { LAT }^{\circledR} 20 \mathrm{mg} / \mathrm{kg} \text { at } 105 \text { and } \\
120 \text { days of gestation }\end{array}$ & PCR & Vaginal mucus & $6 / 25$ & [19] \\
\hline 57 & $\begin{array}{c}\text { LAT }^{\circledR} 20 \mathrm{mg} / \mathrm{kg} \text { at } 105 \text { and } \\
120 \text { days of gestation }\end{array}$ & PCR & Vaginal mucus & $6 / 57(11)$ & [19] \\
\hline 23 & $\begin{array}{c}\text { LAT }^{\circledR} 20 \mathrm{mg} / \mathrm{kg} \text { at } 105 \text { and } \\
120 \text { days of gestation }\end{array}$ & PCR & Vaginal mucus & $5^{\mathrm{d}} / 17(41)$ & [19] \\
\hline 55 & $\begin{array}{c}\text { LAT }^{\circledR} 20 \mathrm{mg} / \mathrm{kg} \text { at } 105 \text { and } \\
120 \text { days of gestation }\end{array}$ & PCR & Vaginal mucus & $2 \mathrm{e} / 53$ & [19] \\
\hline 29 & $\begin{array}{c}\text { LAT }^{\circledR} 20 \mathrm{mg} / \mathrm{kg} \text { at } 105 \text { and } \\
120 \text { days of gestation }\end{array}$ & PCR & Vaginal mucus & $4 / 25(16)$ & [19] \\
\hline
\end{tabular}

a LAT $^{\circledR}$ : Long Action Terramycine.

${ }^{\mathrm{b}}$ One cow shed $C$ burnetii in milk during the first week of treatment and the second one during 4 weeks.

c All these ewes belong to the same flock but they were bred by small groups with 23-57 lambings each month. None of these ewes shed $C$. burnetii during the following gestation.

$\mathrm{d} 2$ ewes aborted in this group.

e 1 ewe aborted in this group.

which could disseminate the pathogen by people wearing protective gears, i.e. gloves, boots, masks.

Manure must be covered and composted or treated with lime or calcium Cyanamide $0.4 \%$ [7] before being spread on the field, which could also spread the disease far away; spreading of manure must never be performed when the wind blows.

Antibiotic treatments with tetracyclines can be used to reduce the number of abortions and the quantities of $C$. burnetii shed at parturition [12, 17, 184] (Tab. V). However, real time PCR should be used to establish the efficiency of an antibiotic at a commonly used dosage. Indeed, in humans it is necessary to associate doxyxycline and hydrochloroquine daily during 18 months to 36 months in order to cure chronic Q fever [130]. Acute Q fever in humans resolves most often spontaneously and when Q fever is diagnosed by serology the patient is convalescent. When antibiotics are used, tetracycline and doxycycline are the most used to treat acute $\mathrm{Q}$ fever [82].

Pasteurization at $72{ }^{\circ} \mathrm{C}$ during $15 \mathrm{~s}$, or sterilization of milk from infected flocks is regularly recommended even if the oral route is not the main one. However, since $\mathrm{Q}$ fever is widely under-diagnosed, practitioners as well as professionally exposed individuals (e.g. people working with ruminant and ruminant products, veterinary surgeons, laboratory workers including researchers studying ruminants), people living near areas with infected flocks and hunters, must be informed about the various symptoms of the disease.

Identification by serology and PCR and slaughter of animals shedding $C$. burnetii in 
placenta, feces or milk is inadequate to eradicate the disease in a flock or an area since $C$. burnetii is able to survive for long periods in the environment and in wild animals. The only way to really prevent the disease in ruminants is to vaccinate uninfected flocks, with an efficient vaccine. The large use of such a vaccine in cattle in Slovakia in the 1970s and 1980s has significantly reduced the occurrence of $\mathrm{Q}$ fever in this country $[82,141]$.

\section{VACCINES}

Current vaccines used in humans and animals include formalin-killed whole-cell vaccine preparations (WCV) [93] and chloroform methanol-extracted bacterial residue (CMR) [47, 175, 183]. The two types of vaccines (WCV and CMR) protect monkeys (Macaca fascicularis) against fever and bacteremia (especially in the lungs) after challenge with an aerosol [176]. They also induce protection on mice and guinea pigs challenged with virulent phase I $C$. burnetii by aerosol [175] or intra-peritoneal injection $[75,190]$. Adverse reactions such as local skin reactions, fever, anorexia, and malaise induced by WCV vaccines in humans and guinea pigs in previously sensitized individuals have been described [74, 179]. A WCV from the Henzerling strain (Q vax, CSL Limited, Parkville, Victoria, Australia) has been commercially available and used for human vaccination in Australia since 1989. Pre-vaccination serological test and skin test with $0.02 \mathrm{mg}$ of the vaccine are recommended in order to avoid reactions at the inoculation site. This vaccine has provided a full and lasting protection by preventing severe cases of $\mathrm{Q}$ fever [93]. It could be very useful in the protection of exposed populations and particularly in female veterinarians. In Russia, a live attenuated human vaccine is produce with the attenuated M-44 strain of C. burnetii [46]. However, Freylikhman et al. have demonstrated the long-term persistence of the bacteria in mice through 3 generations after immunizing the mice with the attenuated M-44 strain at the first generation [46]. Because of the risk of chronic Q fever, the advantage of this attenuated vaccine should be carefully measured. Therefore, the use of vaccines against $Q$ fever in humans is still debated and there are at present no recommendations for vaccination of the general public. A risk analysis is absolutely necessary before undertaking preventive vaccination in humans using the present commercially available vaccines [76].

In animals, the most effective vaccines are those composed of inactivated whole phase I bacteria. Bacterial shedding in placentas and milk was strongly reduced in experimental infection or in natural $Q$ fever infection of ewes and cows vaccinated by phase I vaccines [25, 133, 134]. However, for several authors, phase I vaccines failed to prevent shedding in milk in naturally infected cows prior to vaccination [21, 140], underlining that a vaccine can only protect uninfected animals but is not able to treat an infected one. In contrast, a phase II vaccine failed to protect livestock against the $C$. burnetii infection and to prevent the shedding of bacteria by the vaginal route and in milk [39, 41]: the vaccine was not able to prevent abortions nor bacterial shedding in milk, vaginal secretions nor in feces [147]. Phase II vaccination, antibiotherapy, or a combination of both reduced but did not stop the milk excretion of Coxiella by cows $[39,140]$ or by goats [41]. Since contaminated aerosols are the main sources of animal and human contaminations, the control of fecal excretion and placental bacterial discharge is essential. In France, vaccination of animals with an inactivated phase II vaccine is currently widely used when $Q$ fever is diagnosed in a flock because it is the only available vaccine; however, this vaccination with a phase II vaccine fails to prevent human, animal and environmental contaminations [41].

Phase I vaccines are difficult and dangerous to produce, and there is no test that allows to distinguish vaccinated animals 
from infected animals by C. burnetii. Thus, new approaches to develop an effective, safe and broad-use vaccine against $Q$ fever are warranted. Several proteins and LPS have been tested to serve as vaccines against $\mathrm{Q}$ fever. New immunodominant antigens have been identified using sera from experimentally infected mice with Nine Mile phase I, and their protective efficacy of some of them have been evaluated in a sublethal challenge model in $\mathrm{BALB} / \mathrm{c}$ mice using splenomegaly as an indicator of the severity of the infection [191]. In this model, the recombinant fusion proteins have not induced significant protection, although they have generated antibodies to C. burnetii. Earlier studies have shown that purified native proteins may induce full protection in both guinea pigs and mice [182, 192]. New immunodominant antigens have been cloned using the same model of BALB/c mice and preliminary results suggest that they could be used for the development of novel and specific diagnostic assays and subunit vaccines against $\mathrm{Q}$ fever [190]. The protection conferred by these native or recombinant proteins has just been tested in laboratory animals and these candidate vaccines have not yet been tested in domestic animals and compared with the whole cell phase I vaccine in such models.

Recent works on animal vaccination have shown that the vaccines allow strong reduction of the shedding of $C$. burnetii. These results are very important because limiting the clinical disease in animals is insufficient to prevent animal and human contaminations. Association of diagnosis, especially the use of PCR, with animal vaccination would permit to set up a better surveillance of $\mathrm{Q}$ fever in livestock, and also in human $\mathrm{Q}$ fever.

\section{CONCLUSION}

Q fever has been described since the 1930s and cannot be defined as an emerging zoonotic disease. Re-emergence of Q fever could be explained by the improvement of the diagnosis for which serological tests and PCR allow an accurate detection of the infected flocks or by an enhanced vigilance of practitioners in a front of a flu-like syndrome or an unexplained fever. The high prevalence of acute $Q$ fever in France could reflect such a vigilance even if the mandatory notification of Q fever by physicians, veterinarians and laboratories does not exist in France, on the contrary to other countries in Europe [5]. This underlines that mandatory notification is not always the accurate solution for a better knowledge of epidemiology. Currently in France, this measure is not desirable in veterinary medicine until more data on the disease become available in order to propose validated methods to efficiently prevent the transmission of the disease to humans. Indeed it is necessary to obtain more data on the bacteria, in particular on molecular markers and virulence factors in order to precisely identify the origin of each human infection and to better understand the mechanisms leading to various clinical manifestations in humans and ruminants. Most of the outbreaks of Q fever in humans are related to sheep but until now we have not known if the $C$. burnetii isolated from sheep are more virulent than those isolated from goats and cattle or why sheep preferentially shed $C$. burnetii in vaginal mucus and feces, whatever the virulence of the strain. It would also be interesting to know if the animals with persistent shedding of the bacteria, especially cattle and goats which shed $C$. burnetii in milk during consecutive lactations, have the same antibody patterns against phase I and phase II antigens as humans suffering from chronic $\mathrm{Q}$ fever. Moreover, the efficiency of antibiotic treatments in ruminants on bacterial shedding has to be accurately evaluated. However it is necessary to inform the persons at risk, immunodeficient patients or those suffering from cardiac valvuopathy and pregnant women that they must avoid contact with cows, ewes and goats delivering their calves, lambs and kids. 


\section{REFERENCES}

[1] Abe T., Yamaki K., Hayakawa T., Fukuda H., Ito Y., Kume H., Komiya T., Ishihara K., Hirai K., A seroepidemiological study of the risks of Q fever infection in Japanese veterinarians, Eur. J. Epidemiol. 17 (2001) 10291032.

[2] Abinanti F.R., Welsh H.H., Winn J.F., Lennette E.H., Q fever studies. XIX. Presence and epidemiologic significance of Coxiella burnetii in sheep wool, Am. J. Hyg. 61 (1955) 362.

[3] Amano K., Williams J.C., Sensitivity of Coxiella burnetii peptidoglycan to lysozyme hydrolysis and correlation of sacculus rigidity with peptidoglycan-associated proteins, J. Bacteriol. 160 (1984) 989-993.

[4] Amano K., Williams J.C., Missler S.R., Reinhold V.N., Structure and biological relationships of Coxiella burnetii lipopolysaccharides, J. Biol. Chem. 262 (1987) 4740-4747.

[5] Anonymous, Q fever in Europe, Euro Surveill. 2 (1997) 13-15.

[6] Ariga T., Nagaoka H., Miyanoshita A., Kusunoki Y., Watanabe T., Shinohara T., Sakiyama Y., Coxiella burnetii lymphadenitis: a possible fever focus in acute $\mathrm{Q}$ fever, Pediatr. Int. 42 (2000) 711-714.

[7] Arricau-Bouvery N., Souriau A., Moutoussamy A., Ladenise K., Rodolakis A., Étude de l'excrétion de Coxiella burnetii dans un modèle expérimental caprin et décontamination des lisiers par la cyanamide calcique, Renc. Rech. Ruminants 8 (2001) 153-156.

[8] Arricau-Bouvery N., Souriau A., Lechopier P., Rodolakis A., Experimental Coxiella burnetii infection in pregnant goats: excretion routes, Vet. Res. 34 (2003) 423-433.

[9] Ayres J.G., Flint N., Smith E.G., Tunnicliffe W.S., Fletcher T.J., Hammond K., Ward D., Marmion B.P., Post-infection fatigue syndrome following Q fever, Q. J. Med. 91 (1998) 105-123.

[10] Babudieri B., Q fever: a zoonosis, Adv. Vet. Sci. 5 (1959) 81-154.

[11] Baca O.G., Paretsky D., Q fever and Coxiella burnetii: a model for host-parasite interactions, Microbiol. Rev. 47 (1983) 127-149.

[12] Behymer D., Ruppanner R., Riemann H.P., Biberstein E.L., Franti C.E., Observation on chemotherapy in cows chronically infected with Coxiella burnetii (Q fever), Folia Vet. Lat. 7 (1977) 64-70.

[13] Benson W.W., Brock D.W., Mather J., Serologic analysis of a penitentiary group using raw milk from a $Q$ fever infected herd, Public Health Rep. 78 (1963) 707-710.
[14] Bernit E., Pouget J., Janbon F., Dutronc H., Martinez P., Brouqui P., Raoult D., Neurological involvement in acute $Q$ fever: a report of 29 cases and review of the literature, Arch. Intern. Med. 162 (2002) 693-700.

[15] Berri M., Laroucau K., Rodolakis A., The detection of Coxiella burnetii from ovine genital swabs, milk and fecal samples by the use of a single touchdown polymerase chain reaction, Vet. Microbiol. 72 (2000) 285-293.

[16] Berri M., Souriau A., Crosby M., Crochet D., Lechopier P., Rodolakis A., Relationships between the shedding of Coxiella burnetii, clinical signs and serological responses of 34 sheep, Vet. Rec. 148 (2001) 502-505.

[17] Berri M., Souriau A., Crosby M., Rodolakis A., Shedding of Coxiella burnetii in ewes in two pregnancies following an episode of Coxiella abortion in a sheep flock, Vet. Microbiol. 85 (2002) 55-60.

[18] Berri M., Rousset E., Champion J.L., ArricauBouvery N., Russo P., Pepin M., Rodolakis A., Ovine manure used as a garden fertiliser is suspected to be a contamination source of two human Q fever cases, Vet. Rec. 153 (2003) 269-270.

[19] Berri M., Crochet D., Santiago S., Rodolakis A., Spread of Coxiella burnetii infection in sheep flock and their lamb after a Q fever episode, Vet. Rec. 180 (2005) in press.

[20] Biberstein E.L., Behymer D.E., Bushnell R., Crensshaw G., Riemann H.P., Franti C.E., A survey of Q fever (Coxiella burnetii) in California dairy cows, Am. J. Vet. Res. 35 (1974) 1577-1582.

[21] Biberstein E.L., Riemann H.P., Franti C.E., Behymer D.E., Ruppanner R., Bushnell R., Crenshaw G., Vaccination of dairy cattle against Q fever (Coxiella burnetii): results of field trials, Am. J. Vet. Res. 38 (1977) 189-193.

[22] Bolanos M., Santana O.E., Angel-Moreno A., Perez-Arellano J.L., Liminana J.M., SerraMajem L., Martin-Sanchez A.M., Seroprevalence of infection by Coxiella burnetii in Canary Islands (Spain), Eur. J. Epidemiol. 18 (2003) 259-262.

[23] Boschini A., Di Perri G., Legnani D., Fabbri P., Ballarini P., Zucconi R., Boros S., Rezza G., Consecutive epidemics of $Q$ fever in a residential facility for drug abusers: impact on persons with human immunodeficiency virus infection, Clin. Infect. Dis. 28 (1999) 866872.

[24] Bottieau E., De Raeve H., Colebunders R., Van den Ende J., Vervoort T., Van Marck E., $\mathrm{Q}$ fever after a journey in Syria: a diagnosis suggested by bone marrow biopsy, Acta Clin. Belg. 55 (2000) 30-33. 
[25] Brooks D.L., Ermel R.W., Franti C.E., Ruppanner R., Behymer D.E., Williams J.C., Stephenson J.C., Q fever vaccination of sheep: challenge of immunity in ewes, Am. J. Vet. Res. 47 (1986) 1235-1238.

[26] Bruneval P., Choucair J., Paraf F., Casalta J.P., Raoult D., Scherchen F., Mainardi J., Detection of fastidious bacteria in cardiac valves in cases of blood culture negative endocarditis, J. Clin. Pathol. 54 (2001) 238-240.

[27] Capuano F., Landolfi M.C., Monetti D.M., Influence of three types of farm management on the seroprevalence of Q fever as assessed by an indirect immunofluorescence assay, Vet. Rec. 149 (2001) 669-671.

[28] Carrieri M.P., Tissot-Dupont H., Rey D., Brousse P., Renard H., Obadia Y., Raoult D., Investigation of a slaughterhouse-related outbreak of Q fever in the French Alps, Eur. J. Clin. Microbiol. Infect. Dis. 21 (2002) 17-21.

[29] Castelnovo G., Sotto A., Bouly S., Vladut M., Janbon F., Labauge P., Meningo encephalitis revealing $Q$ fever: two cases and a review of the literature, Rev. Neurol. (Paris) 158 (2002) 77-80 (in French).

[30] Cetinkaya B., Kalender H., Ertas H.B., Muz A., Arslan N., Ongor H., Gurcay M., Seroprevalence of coxiellosis in cattle, sheep and people in the east of Turkey, Vet. Rec. 146 (2000) 131-136.

[31] Chong A.K., La Brooy J., Norton R., Masson J., Q fever: a recent "outbreak" in Townsville, Intern. Med. J. 33 (2003) 208-210.

[32] CisakE., Chmielewska-Badora J., Mackiewicz B., Dutkiewicz J., Prevalence of antibodies to Coxiella burnetii among farming population in eastern Poland, Ann. Agric. Environ. Med. 10 (2003) 265-267.

[33] Cole S.T., Eiglmeier K., Parkhill J., James K.D., Thomson N.R., Wheeler P.R., Honore N., Garnier T., Churcher C., Harris D., Mungall K., Basham D., Brown D., Chillingworth T., Connor R., Davies R.M., Devlin K., Duthoy S., Feltwell T., Fraser A., Hamlin N., Holroyd S., Hornsby T., Jagels K., Lacroix C., Maclean J., Moule S., Murphy L., Oliver K., Quail M.A., Rajandream M.A., Rutherford K.M., Rutter S., Seeger K., Simon S., Simmonds M., Skelton J., Squares R., Squares S., Stevens K., Taylor K., Whitehead S., Woodward J.R., Barrell B.G., Massive gene decay in the leprosy bacillus, Nature 409 (2001) 1007-1011.

[34] de Alarcon A., Villanueva J.L., Viciana P., Lopez-Cortes L., Torronteras R., Bernabeu M., Cordero E., Pachon J., Q fever: epidemiology, clinical features and prognosis. A study from 1983 to 1999 in the South of Spain, J. Infect. 47 (2003) 110-116.
[35] Dellacasagrande J., Ghigo E., Machergui-El S., Hammami, Toman R., Raoult D., Capo C., Mege J.L., alpha(v)beta(3) integrin and bacterial lipopolysaccharide are involved in Coxiella burnetii-stimulated production of tumor necrosis factor by human monocytes, Infect. Immun. 68 (2000) 5673-5678.

[36] Derrick E.H., Q fever, a new fever entity: clinical features, diagnosis and laboratory investigation, Med. J. Aust. 2 (1937) 281-299.

[37] Dindinaud G., Agius G., Burucoa C., Senet J.M., Deshayes M., Magnin G., Castets M., $\mathrm{Q}$ fever and fetal death in utero. Two cases, J. Gynecol. Obstet. Biol. Reprod. (Paris) 20 (1991) 969-972 (in French).

[38] Dupuis G., Petite J., Peter O., Vouilloz M., An important outbreak of human $Q$ fever in a Swiss Alpine valley, Int. J. Epidemiol. 16 (1987) 282-287.

[39] Durand M.P., L'excrétion lactée et placentaire de Coxiella burnetii, agent de la fièvre $\mathrm{Q}$, chez la vache. Importance et prévention, Bull. Acad. Natl. Med. 177 (1993) 935-945; discussion 945-946.

[40] Field P.R., Mitchell J.L., Santiago A., Dickeson D.J., Chan S.W., Ho D.W., Murphy A.M., Cuzzubbo A.J., Devine P.L., Comparison of a commercial enzyme-linked immunosorbent assay with immunofluorescence and complement fixation tests for detection of Coxiella burnetii ( $\mathrm{Q}$ fever) immunoglobulin M, J. Clin. Microbiol. 38 (2000) 1645-1647.

[41] Fishbein D.B., Raoult D., A cluster of Coxiella burnetii infections associated with exposure to vaccinated goats and their unpasteurized dairy products, Am. J. Trop. Med. Hyg. 47 (1992) 35-40.

[42] Fournier P.E., Raoult D., Comparison of PCR and serology assays for early diagnosis of acute Q fever, J. Clin. Microbiol. 41 (2003) 5094-5098.

[43] Fournier P.E., Casalta J.P., Piquet P., Tournigand P., Branchereau A., Raoult D., Coxiella burnetii infection of aneurysms or vascular grafts: report of seven cases and review, Clin. Infect. Dis. 26 (1998) 116-121.

[44] Fournier P.E., Marrie T.J., Raoult D., Diagnosis of Q fever, J. Clin. Microbiol. 36 (1998) 1823-1834.

[45] Fournier P.E., Etienne J., Harle J.R., Habib G., Raoult D., Myocarditis, a rare but severe manifestation of Q fever: report of 8 cases and review of the literature, Clin. Infect. Dis. 32 (2001) 1440-1447.

[46] Freylikhman O., Tokarevich N., Suvorov A. Vorobiova E., Totolian A., Coxiella burnetii persistence in three generations of mice after application of live attenuated human M-44 
vaccine against $Q$ fever, Ann. NY Acad. Sci. 990 (2003) 496-499.

[47] Fries L.F., Waag D.M., Williams J.C., Safety and immunogenicity in human volunteers of a chloroform-methanol residue vaccine for $\mathrm{Q}$ fever, Infect. Immun. 61 (1993) 1251-1258.

[48] Gami A.S., Antonios V.S., Thompson R.L., Chaliki H.P., Ammash N.M., Q fever endocarditis in the United States, Mayo Clin. Proc. 79 (2004) 253-257.

[49] Gardon J., Heraud J.M., Laventure S., Ladam A., Capot P., Fouquet E., Favre J., Weber S., Hommel D., Hulin A., Couratte Y., Talarmin A., Suburban transmission of Q fever in French Guiana: evidence of a wild reservoir, J. Infect. Dis. 184 (2001) 278-284.

[50] Garner M.G., Longbottom H.M., Cannon R.M., Plant A.J., A review of Q fever in Australia 1991-1994, Aust. N. Z. J. Public Health 21 (1997) 722-730.

[51] Gilroy N., Formica N., Beers M., Egan A., Conaty S., Marmion B., Abattoir-associated Q fever: a $Q$ fever outbreak during a $Q$ fever vaccination program, Aust. N. Z. J. Public Health (2001) 362-367.

[52] Greenslade E., Beasley R., Jennings L., Woodward A., Weinstein P., Has Coxiella burnetii ( $\mathrm{Q}$ fever) been introduced into New Zealand? Emerg. Infect. Dis. 9 (2003) 138140.

[53] Hackstadt T., Williams J.C., Biochemical stratagem for obligate parasitism of eukaryotic cells by Coxiella burnetii, Proc. Natl. Acad. Sci. USA 78 (1981) 3240-3244.

[54] Hatchette T.F., Hudson R.C., Schlech W.F., Campbell N.A., Hatchette J.E., Ratnam S., Raoult D., Donovan C., Marrie T.J., Goatassociated Q fever: a new disease in newfoundland, Emerg. Infect. Dis. 7 (2001) 413-419.

[55] Heinzen R.A., Hackstadt T., A developmental stage-specific histone $\mathrm{H} 1$ homolog of Coxiella burnetii, J. Bacteriol. 178 (1996) 5049-5052.

[56] Heinzen R.A., Howe D., Mallavia L.P., Rockey D.D., Hackstadt T., Developmentally regulated synthesis of an unusually small, basic peptide by Coxiella burnetii, Mol. Microbiol. 22 (1996) 9-19.

[57] Heinzen R.A., Hackstadt T., Samuel J.E., Developmental biology of Coxiella burnetii, Trends Microbiol. 7 (1999) 149-154.

[58] Hellenbrand W., Breuer T., Petersen L., Changing epidemiology of Q fever in Germany, 1947-1999, Emerg. Infect. Dis. 7 (2001) 789-796.

[59] Hellmeyer L., Schmitz-Ziegler G., Slenczka W., Schmidt S., Q fever in pregnancy: a case report and review of the literature, Z. Geburtshilfe Neonatol. 206 (2002) 193-198 (in German).

[60] Hendrix L.R., Samuel J.E., Mallavia L.P., Differentiation of Coxiella burnetii isolates by analysis of restriction-endonucleasedigested DNA separated by SDS-PAGE, J. Gen. Microbiol. 137 (1991) 269-276.

[61] Hilbink F., Penrose M., Kovacova E., Kazar J., Q fever is absent from New Zealand, Int. J. Epidemiol. 22 (1993) 945-949.

[62] Honstettre A., Ghigo E., Moynault A., Capo C., Toman R., Akira S., Takeuchi O., Lepidi H., Raoult D., Mege J.L., Lipopolysaccharide from Coxiella burnetii is involved in bacterial phagocytosis, filamentous actin reorganization, and inflammatory responses through Toll-like receptor 4, J. Immunol. 172 (2004) 3695-3703.

[63] Hoover T.A., Vodkin M.H., Williams J.C., A Coxiella burnetii repeated DNA element resembling a bacterial insertion sequence, $\mathrm{J}$. Bacteriol. 174 (1992) 5540-5548.

[64] Hoover T.A., Culp D.W., Vodkin M.H., Williams J.C., Thompson H.A., Chromosomal DNA deletions explain phenotypic characteristics of two antigenic variants, phase II and RSA 514 (crazy), of the Coxiella burnetii nine mile strain, Infect. Immun. 70 (2002) 6726-6733.

[65] Hotta A., Kawamura M., To H., Andoh M., Yamaguchi T., Fukushi H., Hirai K., Phase variation analysis of Coxiella burnetii during serial passage in cell culture by use of monoclonal antibodies, Infect. Immun. 70 (2002) 4747-4749.

[66] Howe D., Mallavia L.P., Coxiella burnetii exhibits morphological change and delays phagolysosomal fusion after internalization by J774A.1 cells, Infect. Immun. 68 (2000) 3815-3821.

[67] Howe D., Melnicakova J., Barak I., Heinzen R.A., Fusogenicity of the Coxiella burnetii parasitophorous vacuole, Ann. NY Acad. Sci. 990 (2003) 556-562.

[68] Howe D., Melnicakova J., Barak I., Heinzen R.A., Maturation of the Coxiella burnetii parasitophorous vacuole requires bacterial protein synthesis but not replication, Cell. Microbiol. 5 (2003) 469-480.

[69] Ibrahim I.N., Okabayashi T., Ristiyanto Lestari E.W., Yanase T., Muramatsu Y., Ueno H., Morita C., Serosurvey of wild rodents for Rickettsioses (spotted fever, murine typhus and Q fever) in Java Island, Indonesia, Eur. J. Epidemiol. 15 (1999) 89-93.

[70] Jäger C., Lautenschläger S., Willems H., Baljer G., Coxiella burnetii plasmid types 
QpDG and QpH1 are closely related and likely identical, Vet. Microbiol. 89 (2002) 161-166.

[71] Janssens S., Beyaert R., Role of Toll-like receptors in pathogen recognition, Clin. Microbiol. Rev. 16 (2003) 637-646.

[72] Kagawa F.T., Wehner J.H., Mohindra V., Q fever as a biological weapon, Semin. Respir. Infect. 18 (2003) 183-195.

[73] Kawamoto T., Ogawa M., Kishimoto T., Uchida Y., Kato K., Kawamoto A., Yamashita T., Three imported cases of acute Q fever after an inspection tour to Australia and New Zealand, Kansenshogaku Zasshi 76 (2002) 1030-1034 (in Japanese).

[74] Kazar J., Brezina R., Palanova A., Tvrda B., Schramek S., Immunogenicity and reactogenicity of a $\mathrm{Q}$ fever chemovaccine in persons professionally exposed to $\mathrm{Q}$ fever in Czechoslovakia, Bull. World Health Organ. 60 (1982) 389-394.

[75] Kazar J., Gajdosova E., Kovacova E., Valkova D., Immunogenicity and protective ability of corpuscular and soluble vaccines prepared from different Coxiella burnetii phase I strains, Acta Virol. 39 (1995) 243-249.

[76] Kermode M., Yong K., Hurley S., Marmion B., An economic evaluation of increased uptake in $\mathrm{Q}$ fever vaccination among meat and agricultural industry workers following implementation of the National Q fever Management Program, Aust. N. Z. J. Public Health 27 (2003) 390-398.

[77] Ko W.C., Liang C.C., Chen H.Y., Chuang Y.C., Seroprevalence of Coxiella burnetii infection in southern Taiwan, J. Formos. Med. Assoc. 99 (2000) 33-38.

[78] Kocianova E., Kovacova E., Literak I., Comparison of virulence of Coxiella burnetii isolates from bovine milk and from ticks, Folia Parasitol. 48 (2001) 235-239.

[79] Komiya T., Sadamasu K., Kang M.I., Tsuboshima S., Fukushi H., Hirai K., Seroprevalence of Coxiella burnetii infections among cats in different living environments, J. Vet. Med. Sci. 65 (2003) 1047-1048.

[80] Komiya T., Sadamasu K., Toriniwa H., Kato K., Arashima Y., Fukushi H., Hirai K., Arakawa Y., Epidemiological survey on the route of Coxiella burnetii infection in an animal hospital, J. Infect. Chemother. 9 (2003) 151-155.

[81] Kovacova E., Kazar J., Spanelova D., Suitability of various Coxiella burnetii antigen preparations for detection of serum antibodies by various tests, Acta Virol. 42 (1998) 365-368.
[82] Kovacova E., Kazar J., Q fever-still a query and underestimated infectious disease, Acta Virol. 46 (2002) 193-210.

[83] Krumbiegel E.R., Wisniewski H.J., Q fever in the Milwaukee area. II. Consumption of infected raw milk by human volunteers, Arch. Environ. Health 21 (1970) 63-65.

[84] Kubota H., Tanabe Y., Komiya T., Hirai K., Takanashi J., Kohno Y., Q fever encephalitis with cytokine profiles in serum and cerebrospinal fluid, Pediatr. Infect. Dis. J. 20 (2001) 318-319.

[85] La Scola B., Raoult D., Survival of Coxiella burnetii within free-living amoeba Acanthamoeba castellanii, Clin. Microbiol. Infect. 7 (2001) 75-79.

[86] Lang G.H., Coxiellosis (Q fever) in animals, CRC press, Boca Raton, 1990, pp. 23-48.

[87] Langley J.M., Marrie T.J., Leblanc J.C., Almudevar A., Resch L., Raoult D., Coxiella burnetii seropositivity in parturient women is associated with adverse pregnancy outcomes, Am. J. Obstet. Gynecol. 189 (2003) 228-232.

[88] Lautenschlager S., Willems H., Jager C., Baljer G., Sequencing and characterization of the cryptic plasmid QpRS from Coxiella burnetii, Plasmid 44 (2000) 85-88.

[89] Lee J.H., Park H.S., Jang W.J., Koh S.E., Park T.K., Kang S.S., Kim B.J., Kook Y.H., Park K.H., Lee S.H., Identification of the Coxiella sp. detected from Haemaphysalis longicornis ticks in Korea, Microbiol. Immunol. 48 (2004) 125-130.

[90] Lepe J.A., Guerrero F.J., Ruiz-Calderon A., del Castillo E., Gomez-Salvago S., JimenezAlonso M.A., Palomo S., Perea R., The epidemiology of $Q$ fever in the northern area of Huelva, Spain, Enferm. Infecc. Microbiol. Clin. 17 (1999) 65-68 (in Spanish).

[91] Lyytikainen O., Ziese T., Schwartlander B., Matzdorff P., Kuhnhen C., Burger C., Krug W., Petersen L.R., Outbreak of Q fever in Lohra-Rollshausen, Germany, spring 1996, Euro Surveill. 2 (1997) 9-11.

[92] Madariaga M.G., Rezai K., Trenholme G.M., Weinstein R.A., Q fever: a biological weapon in your backyard, Lancet Infect. Dis. 3 (2003) 709-721.

[93] Marmion B.P., Ormsbee R.A., Kyrkou M., Wright J., Worswick D.A., Izzo A.A., Esterman A., Feery B., Shapiro R.A., Vaccine prophylaxis of abattoir-associated Q fever: eight years' experience in Australian abattoirs, Epidemiol. Infect. 104 (1990) 275-287.

[94] Marrie T.J., Q fever, 1979-1987-Nova Scotia, Can. Dis. Wkly. Rep. 14 (1988) 69-70. 
[95] Marrie T., Acute Q fever, CRC press, Boca Raton, 1990, pp. 125-157.

[96] Marrie T.J., Coxiella burnetii (Q fever) pneumonia, Clin. Infect. Dis. Suppl. 3 (1995) S253-S264.

[97] Marrie T.J., Raoult D., Update on Q fever, including Q fever endocarditis, Curr. Clin. Top. Infect. Dis. 22 (2002) 97-124.

[98] Marrie T.J., Haldane E.V., Noble M.A., Faulkner R.S., Lee S.H., Gough D., Meyers S., Stewart J., Q fever in maritime Canada, Can. Med. Assoc. J. 126 (1982) 1295-1300.

[99] Marrie T.J., Schlech W.F. 3rd, Williams J.C., Yates L., Q fever pneumonia associated with exposure to wild rabbits, Lancet 1 (1986) 427-429.

[100] Masala G., Porcu R., Sanna G., Chessa G., Cillara G., Chisu V., Tola S., Occurrence, distribution, and role in abortion of Coxiella burnetii in sheep and goats in Sardinia, Italy, Vet. Microbiol. 99 (2004) 301-305.

[101] Maurin M., Raoult D., Q fever, Clin. Microbiol. Rev. 12 (1999) 518-553.

[102] McCaul T.F., Williams J.C., Developmental cycle of Coxiella burnetii: structure and morphogenesis of vegetative and sporogenic differentiations, J. Bacteriol. 147 (1981) 10631076.

[103] McCaul T.F., Banerjee-Bhatnagar N., Williams J.C., Antigenic differences between Coxiella burnetii cells revealed by postembedding immunoelectron microscopy and immunoblotting, Infect. Immun. 59 (1991) 3243-3253.

[104] McDiarmid L., Petney T., Dixon B., Andrews R., Range expansion of the tick Amblyomma triguttatum triguttatum, an Australian vector of Q fever, Int. J. Parasitol. 30 (2000) 791-793.

[105] McQuiston J.H., Childs J.E., Q fever in humans and animals in the United States, Vector Borne Zoonotic Dis. 2 (2002) 179191.

[106] Mejia A., Toursarkissian B., Hagino R.T., Myers J.G., Sykes M.T., Primary aortoduodenal fistula and Q fever: an underrecognized association? Ann. Vasc. Surg. 14 (2000) 271-273.

[107] Melnicakova J., Lukacova M., Howe D., Heinzen R.A., Barak I., Identification of Coxiella burnetii RpoS-dependent promoters, Ann. NY Acad. Sci. 990 (2003) 591-595.

[108] Miljak T., Mahl C., Hofgartner F., Rostan R., Sigel H., A rare cause of myocarditis in a 30year-old patient, Med. Klin. (Munich) 95 (2000) 645-648 (in German).

[109] Montejo Baranda M., Corral Carranceja J., Aguirre Errasti C., Q fever in the Basque
Country: 1981-1984, Rev. Infect. Dis. 7 (1985) 700-701.

[110] Montes M., Cilla G., Marimon J.M., Diaz de Tuesta J.L., Perez-Trallero E., Coxiella burnetii infection in subjects with HIV infection and HIV infection in patients with Q fever, Scand. J. Infect. Dis. 27 (1995) 344-346.

[111] Navarro J., Martinez M.L., Iniesta J.A., Palazon D., Cano A., A case of Q fever manifested solely as meningoencephalitis, Eur. J. Clin. Microbiol. Infect. Dis. 20 (2001) 361-362.

[112] Ning Z., Yu S.R., Quan Y.G., Xue Z., Molecular characterization of cloned variants of Coxiella burnetii isolated in China, Acta Virol. 36 (1992) 173-183.

[113] Norlander L., Q fever epidemiology and pathogenesis, Microbes Infect. 2 (2000) 417 424.

[114] Numazaki K., Ueno H., Yokoo K., Muramatsu Y., Chiba S., Morita C., Detection of serum antibodies to Bartonella henselae and Coxiella burnetii from Japanese children and pregnant women, Microbes Infect. 2 (2000) 1431-1434.

[115] Ogata H., Audic S., Renesto-Audiffren P., Fournier P.E., Barbe V., Samson D., Roux V., Cossart P., Weissenbach J., Claverie J.M., Raoult D., Mechanisms of evolution in Rickettsia conorii and $R$. prowazekii, Science 293 (2001) 2093-2098.

[116] Palmer N.C., Kierstead M., Key D.W., Williams J.C., Peacock M.G., Vellend H., Placentitis and abortion in goats and sheep in Ontario caused by Coxiella burnetii, Can. Vet. J. 24 (1983) 60-61.

[117] Pebody R.G., Wall P.G., Ryan M.J., Fairley C., Epidemiological features of Coxiella burnetii infection in England and Wales: 1984 to 1994, Commun. Dis. Rep. CDR Rev. 6 (1996) R128-R132.

[118] Penttila I.A., Harris R.J., Storm P., Haynes D., Worswick D.A., Marmion B.P., Cytokine dysregulation in the post-Q-fever fatigue syndrome, Q. J. Med. 91 (1998) 549-560.

[119] Perez-Flores E., Delas M.A., Iniesta J.A., Artero J.M., Martinez-Navarro M.L., DiazOrtuno A., Partial third nerve palsy caused with chronic Q fever, Eur. J. Neurol. 6 (1999) 619-620.

[120] Post J.J., Konecny P., Lloyd A.R., Jones P.D., Acute $Q$ fever and brachial neuritis: case report and literature review, Infection 30 (2002) 400-402.

[121] Potasman I., Rzotkiewicz S., Pick N., Keysary A., Outbreak of $\mathrm{Q}$ fever following a safari trip, Clin. Infect. Dis. 30 (2000) 214-215. 
[122] Quevedo Diaz M.A., Lukacova M., Immunological consequences of Coxiella burnetii phase variation, Acta Virol. 42 (1998) 181-185.

[123] Raoult D., Host factors in the severity of Q fever, Ann. NY Acad. Sci. 590 (1990) 33-38.

[124] Raoult D., Levy P., Tissot-Dupont H., Chicheportiche C., Tamalet C., Gastaut J.A., Salducci J., Q fever and HIV infection, AIDS 7 (1993) 81-86.

[125] Raoult D., Tissot-Dupont H., Foucault C., Gouvernet J., Fournier P.E., Bernit E., Stein A., Nesri M., Harle J.R., Weiller P.J., Q fever 1985-1998. Clinical and epidemiologic features of 1383 infections, Medicine 79 (2000) 109-123.

[126] Raoult D., Fenollar F., Stein A., Q fever during pregnancy, Arch. Intern. Med. 162 (2002) 701-704.

[127] Reintjes R., Hellenbrand W., Dusterhaus A. Q-fever outbreak in Dortmund in the summer of 1999. Results of an epidemiological outbreak study, Gesundheitswesen 62 (2000) 609-614 (in German).

[128] Rexroth G., Rosch W., Altmannsberger M., Bone marrow granulomatosis in Q-fever, Med. Klin. (Munich) 95 (2000) 404-408 (in German).

[129] Rey D., Obadia Y., Tissot-Dupont H., Raoult D., Seroprevalence of antibodies to Coxiella burnetti among pregnant women in South Eastern France, Eur. J. Obstet. Gynecol. Reprod. Biol. 93 (2000) 151-156.

[130] Rolain J.M., Mallet M.N., Raoult D., Correlation between serum doxycycline concentrations and serologic evolution in patients with Coxiella burnetii endocarditis, J. Infect. Dis. 188 (2003) 1322-1325.

[131] Romero-Jimenez M.J., Suarez-Lozano I., Fajardo J.M., Benavente A., Menchero A., de la Iglesia A., Hepatitis as unique manifestation of $\mathrm{Q}$ fever: clinical and epidemiologic characteristics in 109 patients, Enferm. Infecc. Microbiol. Clin. 21 (2003) 193-195 (in Spanish).

[132] Rousset E., Russo P., Pépin M., Raoult D., Epidémiologie de la fièvre $Q$ animale. Situation en France, Méd. Mal. Infect. 31 (2001) 233-246.

[133] Sadecky E., Brezina R., Kazar J., Urvolgyi J., Immunization against Q-fever of naturally infected dairy cows, Acta Virol. 19 (1975) 486-488.

[134] Sadecky E., Brezina R., Vaccination of naturally infected ewes against Q-fever, Acta Virol. 21 (1977) 89.

[135] Sampere M., Font B., Font J., Sanfeliu I., Segura F., Q fever in adults: review of 66 clinical cases, Eur. J. Clin. Microbiol. Infect. Dis. 22 (2003) 108-110.

[136] Samuel J.E., Kiss K., Varghees S., Molecular pathogenesis of Coxiella burnetii in a genomics era, Ann. NY Acad. Sci. 990 (2003) 653663.

[137] Sanchez R., Baraia-Etxaburu J., Ibarrola M., Teira R., Imaz M., Uterga J.M., Haidar K., Santamaria J.M., Meningoencephalitis with cerebellar involvement associated with Coxiella burnetii pneumonia, Enferm. Infecc. Microbiol. Clin. 19 (2001) 134-136 (in Spanish).

[138] Santoro D., Giura R., Colombo M.C., Antonelli P., Gramegna M., Gandola O., Gridavilla G., Q fever in Como, northern Italy, Emerg. Infect. Dis. 10 (2004) 159-160.

[139] Schelling E., Diguimbaye C., Daoud S., Nicolet J., Boerlin P., Tanner M., Zinsstag J., Brucellosis and Q-fever seroprevalences of nomadic pastoralists and their livestock in Chad, Prev. Vet. Med. 61 (2003) 279-293.

[140] Schmeer N., Müller P., Langel J., Krauss H., Frost J.W., Wieda J., Q fever vaccines for animals, Zentralbl. Bakteriol. Mikrobiol. Hyg. A 267 (1987) 79-88.

[141] Serbezov V.S., Kazar J., Novkirishki V., Gatcheva N., Kovacova E., Voynova V., Q fever in Bulgaria and Slovakia, Emerg. Infect. Dis. 5 (1999) 388-394.

[142] Seshadri R., Samuel J.E., Characterization of a stress-induced alternate Sigma factor, RpoS, of Coxiella burnetii and its expression during the development cycle, Infect. Immun. 69 (2001) 4874-4883.

[143] Seshadri R., Hendrix L.R., Samuel J.E., Differential expression of translational elements by life cycle variants of Coxiella burnetii, Infect. Immun. 67 (1999) 6026-6033.

[144] Seshadri R., Paulsen I.T., Eisen J.A., Read T.D., Nelson K.E., Nelson W.C., Ward N.L., Tettelin H., Davidsen T.M., Beanan M.J., Deboy R.T., Daugherty S.C., Brinkac L.M., Madupu R., Dodson R.J., Khouri H.M., Lee K.H., Carty H.A., Scanlan D., Heinzen R.A., Thompson H.A., Samuel J.E., Fraser C.M., Heidelberg J.F., Complete genome sequence of the Q-fever pathogen Coxiella burnetii, Proc. Natl. Acad. Sci. USA 100 (2003) 54555460.

[145] Sobradillo V., Ansola P., Baranda F., Corral C., Q fever pneumonia: a review of $164 \mathrm{com}-$ munity-acquired cases in the Basque country, Eur. Respir. J. 2 (1989) 263-266.

[146] Sommer J.B., Schoerner C., Heckmann J.G., Neundoerfer B., Hilz M.J., Mononeuritis multiplex caused by Coxiella burnetii infection (Q fever), Acta Neurol. Scand. 106 (2002) 371-373. 
[147] Souriau A., Arricau-Bouvery N., Bodier C., Rodolakis A., Comparison of the efficacy of $\mathrm{Q}$ fever vaccines against Coxiella burnetii experimental challenge in pregnant goats, Ann. NY Acad. Sci. 990 (2003) 521-523.

[148] Speelman D.W., Q fever: a study of 111 consecutive cases, Med. J. Aust. 1 (1982) 547-553.

[149] Splino M., Beran J., Chlibek R., Q fever outbreak during the Czech Army deployment in Bosnia, Mil. Med. 168 (2003) 840-842.

[150] Spyridaki I., Psaroulaki A., Loukaides F., Antoniou M., Hadjichristodolou C., Tselentis Y., Isolation of Coxiella burnetii by a centrifugation shell-vial assay from ticks collected in Cyprus: detection by nested polymerase chain reaction (PCR) and by PCR-restriction fragment length polymorphism analyses, Am. J. Trop. Med. Hyg. 66 (2002) 86-90.

[151] Stein A., Raoult D., Detection of Coxiella burnetii by DNA amplification using polymerase chain reaction, J. Clin. Microbiol. 30 (1992) 2462-2466.

[152] Stein A., Raoult D., Lack of pathotype specific gene in human Coxiella burnetii isolates, Microb. Pathog. 15 (1993) 177-185.

[153] Stein A., Raoult D., Pigeon pneumonia in Provence: a bird-borne Q fever outbreak, Clin. Infect. Dis. 29 (1999) 617-620.

[154] Stein A., Berthet B., Raoult D., A "query" pancreatitis in a young shepherdess: an uncommon manifestation of acute $\mathrm{Q}$ fever, Clin. Infect. Dis. 29 (1999) 445-446.

[155] Stein A., Lepidi H., Mege J.L., Marrie T.J., Raoult D., Repeated pregnancies in BALB/c Mice infected with Coxiella burnetii cause disseminated infection, resulting in stillbirth and endocarditis, J. Infect. Dis. 181 (2000) 188-194.

[156] Steiner H.A., Raveh D., Rudensky B., Paz E., Jerassi Z., Schlesinger Y., Yinnon A.M., Outbreak of Q fever among kitchen employees in an urban hospital, Eur. J. Clin. Microbiol. Infect. Dis. 20 (2001) 898-900.

[157] Stephens R.S., Kalman S., Lammel C., Fan J., Marathe R., Aravind L., Mitchell W., Olinger L., Tatusov R.L., Zhao Q., Koonin E.V., Davis R.W., Genome sequence of an obligate intracellular pathogen of humans: Chlamydia trachomatis, Science 282 (1998) 754-759.

[158] Stevens H., Beeres M.P., Meijer J.G., Koeman J., van Kregten E., Bartelink A.K., Q fever: not just in sheep, Ned. Tijdschr. Geneeskd. 144 (2000) 1297-1300 (in Dutch).

[159] Swanson M.S., Fernandez-Moreia E., A microbial strategy to multiply in macrophages: the pregnant pause, Traffic 3 (2002) 170-177.
[160] Takahashi H., Tokue Y., Kikuchi T., Kobayashi T., Gomi K., Goto I., Shiraishi H., Fukushi H., Hirai K., Nukiwa T., Watanabe A., Prevalence of community-acquired respiratory tract infections associated with $\mathrm{Q}$ fever in Japan, Diagn. Microbiol. Infect. Dis. 48 (2004) 247-252.

[161] Tattevin P., Arvieux C., Dupont M., Guggenbuh P., Lemeur A., Michelet C., Granulomatous lymphadenitis as a manifestation of $\mathrm{Q}$ fever, Emerg. Infect. Dis. 9 (2003) 137-138.

[162] Thiele D., Willems H., Is plasmid based differentiation of Coxiella burnetii in "acute" and "chronic" isolates still valid? Eur. J. Epidemiol. 10 (1994) 427-434.

[163] Thiele D., Willems H., Haas M., Krauss H., Analysis of the entire nucleotide sequence of the cryptic plasmid QpH1 from Coxiella burnettii, Eur. J. Epidemiol. 10 (1994) 413-420.

[164] Thompson H.A., Hoover T.A., Vodkin M.H., Shaw E.I., Do chromosomal deletions in the lipopolysaccharide biosynthetic regions explain all cases of phase variation in Coxiella burnetii strains? An update, Ann. NY Acad. Sci. 990 (2003) 664-670.

[165] Tissot-Dupont H., Raoult D., Brouqui P., Janbon F., Peyramond D., Weiller P.J., Chicheportiche C., Nezri M., Poirier R., Epidemiologic features and clinical presentation of acute Q fever in hospitalized patients: 323 French cases, Am. J. Med. 93 (1992) 427-434.

[166] Tissot-Dupont H., Torres S., Nezri M., Raoult D., Hyperendemic focus of Q fever related to sheep and wind, Am. J. Epidemiol. 150 (1999) 67-74.

[167] To H., Htwe K.K., Yamasaki N., Zhang G.Q., Ogawa M., Yamaguchi T., Fukushi H., Hirai $\mathrm{K}$., Isolation of Coxiella burnetii from dairy cattle and ticks, and some characterization of the isolates in Japan, Microbiol. Immunol. 39 (1995) 663-671.

[168] To H., Htwe K.K., Kako N., Kim H.J., Yamaguchi T., Fukushi H., Hirai K., Prevalence of Coxiella burnetii infection in dairy cattle with reproductive disorders, J. Vet. Med. Sci. 60 (1998) 859-861.

[169] Tobin M.J., Cahill N., Gearty G., Maurer B., Blake S., Daly K., Hone R., Q fever endocarditis, Am. J. Med. 72 (1982) 396-400.

[170] Tselentis Y., Gikas A., Kofteridis D., Kyriakakis E., Lydataki N., Bouros D., Tsaparas N., Q fever in the Greek Island of Crete: epidemiologic, clinical, and therapeutic data from 98 cases, Clin. Infect. Dis. 20 (1995) 1311-1316.

[171] Tujulin E., Lilliehook B., Macellaro A., Sjostedt A., Norlander L., Early cytokine induction in mouse P388D1 macrophages infected by 
Coxiella burnetii, Vet. Immunol. Immunopathol. 68 (1999) 159-168.

[172] Valkova D., Kazar J., A new plasmid (QpDV) common to Coxiella burnetii isolates associated with acute and chronic Q fever, FEMS Microbiol. Lett. 125 (1995) 275-280.

[173] Varghees S., Kiss K., Frans G., Braha O., Samuel J.E., Cloning and porin activity of the major outer membrane protein P1 from Coxiella burnetii, Infect. Immun. 70 (2002) 6741-6750.

[174] Vasselon T., Detmers P.A., Toll receptors: a central element in innate immune responses, Infect. Immun. 70 (2002) 1033-1041.

[175] Waag D.M., England M.J., Pitt M.L., Comparative efficacy of a Coxiella burnetii chloroform:methanol residue (CMR) vaccine and a licensed cellular vaccine $(\mathrm{Q}-\mathrm{Vax})$ in rodents challenged by aerosol, Vaccine 15 (1997) 1779-1783.

[176] Waag D.M., England M.J., Tammariello R.F., Byrne W.R., Gibbs P., Banfield C.M., Pitt M.L., Comparative efficacy and immunogenicity of Q fever chloroform:methanol residue $(\mathrm{CMR})$ and phase I cellular (Q-Vax) vaccines in cynomolgus monkeys challenged by aerosol, Vaccine 20 (2002) 2623-2634.

[177] Welsh H.H., Lennette E.H., Abinanti F.R., Winn J.F., Airborne transmission of Q fever: the role of parturition in generation of infective aerosol, Ann NY Acad. Sci. 70 (1957) 528-540.

[178] Wiebe M.E., Burton P.R., Shankel D.M., Isolation and characterization of two cell types of Coxiella burnetii, J. Bacteriol. 110 (1972) 368-377.

[179] Wilhelmsen C.L., Waag D.M., Guinea pig abscess/hypersensitivity model for study of adverse vaccination reactions induced by use of Q fever vaccines, Comp. Med. 50 (2000) 374-378.

[180] Willems H., Thiele D., Fröhlich-Ritter R., Krauss H., Detection of Coxiella burnetii in cow's milk using the polymerase chain reaction (PCR), J. Vet. Med. Ser. B 41 (1994) 580-587.

[181] Willems H., Ritter M., Jager C., Thiele D., Plasmid-homologous sequences in the chromosome of plasmidless Coxiella burnetii Scurry Q217, J. Bacteriol. 179 (1997) 3293-3297.

[182] Williams J.C., Peacock M.G., McCaul T.F., Immunological and biological characterization of Coxiella burnetii, phases I and II, separated from host components, Infect. Immun. 32 (1981) 840-851.
[183] Williams J.C., Peacock M.G., Waag D.M., Kent G., England M.J., Nelson G., Stephenson E.H., Vaccines against coxiellosis and Q fever. Development of a chloroform:methanol residue subunit of phase I Coxiella burnettii for the immunization of animals, Ann. NY Acad. Sci. 653 (1992) 88-111.

[184] Woernle H., Limouzin C., Muler K., Durand M.P., La fièvre Q bovine. Effet de la vaccination et de l'antibiothérapie sur l'évolution clinique et l'excrétion de Coxiella burnetii dans le lait, Bull. Acad. Natl. Vet. 58 (1985) 91-100.

[185] Woldehiwet Z., Q fever (coxiellosis): epidemiology and pathogenesis, Res. Vet. Sci. 77 (2004) 93-100.

[186] Yohannes K., Roche P., Blumer C., Spencer J., Milton A., Bunn C., Gidding H., Kirk M., Della-Porta T., Australia's notifiable diseases status, 2002: Annual report of the National Notifiable Diseases Surveillance System, Commun. Dis. Intell. 28 (2004) 6-68.

[187] Zamboni D.S., Mortara R.A., Freymuller E., Rabinovitch M., Mouse resident peritoneal macrophages partially control in vitro infection with Coxiella burnetii phase II, Microbes Infect. 4 (2002) 591-598.

[188] Zamboni D.S., McGrath S., Rabinovitch M., Roy C.R., Coxiella burnetii express type IV secretion system proteins that function similarly to components of the Legionella pneumophila Dot/Icm system, Mol. Microbiol. 49 (2003) 965-976.

[189]Zeman D.H., Kirkbride C.A., Leslie-Steen P., Duimstra J.R., Ovine abortion due to Coxiella burnetti infection, J. Vet. Diagn. Invest. 1 (1989) 178-180.

[190] Zhang G., Kiss K., Seshadri R., Hendrix L.R., Samuel J.E., Identification and cloning of immunodominant antigens of Coxiella burnetii, Infect. Immun. 72 (2004) 844-852.

[191] Zhang G.Q., Samuel J.E., Identification and cloning potentially protective antigens of Coxiella burnetii using sera from mice experimentally infected with Nine Mile phase I, Ann. NY Acad. Sci. 990 (2003) 510-520.

[192] Zhang Y.X., Zhi N., Yu S.R., Li Q.J., Yu G.Q., Zhang X., Protective immunity induced by $67 \mathrm{~K}$ outer membrane protein of phase I Coxiella burnetii in mice and guinea pigs, Acta Virol. 38 (1994) 327-332.

[193] Zusman T., Yerushalmi G., Segal G., Functional similarities between the $\mathrm{icm} /$ dot pathogenesis systems of Coxiella burnetii and Legionella pneumophila, Infect. Immun. 71 (2003) 3714-3723. 